\title{
The Church as a Governance Actor in a Period of Post-Imperial Transition: Delegation of Fiscal Rights and Legal Change in 10th-century Churraetia ${ }^{1}$
}

\author{
Stefan Esders*
}

Taking the Alpine region of Churraetia as a case study, this paper investigates processes of fiscal delegation, their preconditions, their legal construction, and their consequences. As Churraetia maintained many features of Roman provincial administration and statehood well into the Carolingian period, the article's first part traces how fiscal revenues and rights came to be delegated to the episcopal church of Chur via royal privilege from the mid-9th century until 960. The delegation of fiscal rights usually happened in special situations when kings and grantees agreed on a closer cooperation in the future. In the course of this process, which in the case of Churraetia eventually turned a former Roman province into an ecclesiastical principality, the episcopal church became a governance actor that would play a crucial rule in exercising public functions such as tax collection, jurisdiction and military recruitment. Ecclesiastical property (often deriving from royal munificence) and fiscal income became indispensable means for performing these functions. The article's second part focuses on the situation of 912 when the newly elected East Frankish king Conrad I, the first ruler of non-Carolingian stock, conferred two special privileges on the episcopal church of Chur: Conrad's grant of the right to conduct inquisition procedure by compulsory witness in order to protect ecclesiastical property effectively meant that procedural law typical for the "public sphere " now came into the hands of the bishop of Chur. Conrad's second stipulation, that the thirty-year period of proscription should not to be applied against the interest of the bishop of Chur, has to be seen against the background of legal pluralism in this region, in which several legal traditions were in conflict: while Roman law allowed a slave to rid himself of his master after thirty years, Aleman law forbade this, just as the idea that ecclesiastical property was regarded as inalienable spoke against the application of the thirty-years rule to the detriment of the church. Responding to ecclesiastical networks supporting his rule, Conrad thus had the Roman legal rule of prescription branded as a »bad custom " (mala consuetudo). As is finally argued in a more general perspective, in historical situations of political transition legal pluralism and legal change could lead to a new qualification of what had formerly been seen in more positive terms as "custom».

Keywords: law; custom; fiscal rights; inquisition procedure; prescription; slavery and serfdom; delegation; Churraetia; polyptychs; royal charters

* Correspondence details: Stefan Esders, Freie Universität Berlin, Friedrich-Meinecke-Institut, Geschichte der Spätantike und des Frühen Mittelalters, Koserstr. 20, 14195 Berlin; email: esdersst@zedat.fu-berlin.de.

1 This work was written as a contribution to the colloquium »Uses of the Past in Times of Transition. Forgetting, using and discrediting the past «, the final conference of the HERA Joint Research Project »After Empire. Using and not using the past in the crisis of the Carolingian world, c. 900-1050«, held in Vienna from 30th May to 1st June 2019. 
In a European perspective, the 10th century appears in many regions as a period of postimperial transition. In the various successor states of the Carolingian Empire we can observe the creation of new arrangements of "power structures " between kings and nobles. These processes seem to have corresponded to a shift in power structures, as one would expect when empires break apart and old governmental structures become regionalized and relations between rulers and nobles become reshaped. An instructive aspect to understand these processes of decentralization is the role played by ecclesiastical actors - monasteries and episcopal churches in particular. As evidence coming from administrative and legal documents preserved in ecclesiastical archives illustrates from a local perspective, these developments did not simply happen via facti, but appear to have been handled in a fairly organized manner.

To a certain extent, these early medieval practices of decentralizing government structures were rooted in administrative traditions of the Roman Empire. The process of delegating political and administrative functions to ecclesiastical institutions in Western Europe - thereby making "the church" a "governance actor « or indeed a "co-producer of statehood $\aleph^{2}-$ can, in some of its features, be traced back to Late Antiquity or more precisely, to late-Roman statehood, if we think, for instance, of episcopal jurisdiction (episcopalis audientia) or the manumission of slaves in the church, both of which were already legally acknowledged by the first Christian emperor Constantine I. ${ }^{3}$ In the post-Roman West, by the Merovingian period we can observe how large monasteries and episcopal churches were granted immunities that entitled them to exact taxes from their dependents, and that also, from the 7th century onward, often included the right to exercise some sort of jurisdiction over its tenants, excluding the royal functionaries from carrying out this kind of business (interdiction of introitus). ${ }^{4}$ In the Carolingian period, the contents of these immunities often became extended, with many monasteries being granted special royal protection. ${ }^{5}$ It is from the 8th century onward that we can see how monasteries and larger churches also became involved in military recruitment so that they constituted a part of the Carolingian army. ${ }^{6}$ Already under Charlemagne, when he ordered the oath of fidelity to be sworn by his subjects in 789 , the crucial role of abbots and bishops in commanding relevant parts of the army is amply visible. ${ }^{7}$ In the 9th century, famous monasteries such as Fulda seem to have exercised quite a number of important secular and indeed military functions, as charters and diplomas illustrate. ${ }^{8} \mathrm{~A}$ further stage in this development can be observed in the Ottonian period, when Carolingian policies of delegating public functions were developed further. ${ }^{9}$ The appointment of bishops and abbots, who had often previously been in royal service in the royal chapel (Hofkapelle), was put more strictly under royal control, ${ }^{10}$ while in the course of the tenth century we can also see how counties were added to bishoprics. ${ }^{11}$ On closer inspection, however, many such

\footnotetext{
For some more general thoughts on this topic, see Esders and Schuppert, Mittelalterliches Regieren. 
developments did not simply emanate from some sort of programmatic policy, but appear to be driven by special situations and local conditions that could vary enormously. ${ }^{12}$ Each case thus deserves a special study that brings to light the individual circumstances where the evidence allows for painting a more nuanced picture.

Churraetia, the Alpine region dealt with in this article, witnessed a less straightforward development during the first centuries of Frankish rule. Raetia Curiensis, the area centred around the city of Chur, which in Roman times was the capital of the province Raetia prima, is well known as a region with a remarkable impact or continuity of Roman culture well into the Carolingian period and after. ${ }^{13}$ Chur continued to be an important place in the early medieval period, as we find the governor of this region often still called a praeses. Churraetia was a Latin-speaking region, and the predominant legal text to be applied within this territory appears to be the Lex Romana Curiensis, ${ }^{14}$ an 8th-century compilation of Roman law based on the Breviary of Alaric, which was also known in Churraetia. ${ }^{15}$ To be sure, there were also Alemanni, Bavarians and Lombards living in this region, but Churraetia was one of the few areas of the Frankish kingdom, and certainly the only one of the East Frankish kingdom, where Roman law was regarded as the dominant legal system, though with certain adjustments. ${ }^{16}$ In fact, several rulers, including Charlemagne as early as 772, had guaranteed that local "law and custom " (lex et consuetudo) be observed in Churraetia, as has been emphasized by Reinhold Kaiser, who also pointed to the Capitula Remedii as an important text originating in Churraetia and revealing a remarkable fusion of Frankish capitulary law and local law, possibly intended as a capitulare legibus addendum. ${ }^{17}$ Moreover, the private charters that have come down to us from Churraetia, including the famous Folcwin dossier from the early 9th century, display a remarkable awareness of Roman legal clauses and figures and point to a legal culture in which trained lay advocates or notaries played a significant role. ${ }^{18}$ The emperor Lothar I, when confirming his predecessors' grants in 843, renewed royal protection for the people (populus) and the bishop of Churraetia stating that no external functionaries should impose unjust laws and customs (iniustas leges et consuetudines inponere).$^{19}$ And still in a placitum of 920, documenting a legal dispute between the bishop of Chur and the abbot of the neighbouring Aleman abbey of St Gall about the abbey of Pfäfers, situated in Raetia, we find an order of the Aleman Duke Burchard that

12 See the criticism of Reuter, "Imperial Church System «, and Hoffmann, Grafschaften in Bischofshand.

13 Kaiser, Churrätien im frühen Mittelalter; on Raetian Romanness, see also Zeller, Romanen, Räter und Walchen.

14 Lex Romana Curiensis, ed. Meyer-Marthaler; Meyer-Marthaler, Römisches Recht in Rätien; Siems, Zur Lex Romana Curiensis.

15 See e.g., Müller, Neue Handschrift.

16 See also Esders, Roman law.

17 Ed. Meyer-Marthaler and Perret, Bündner Urkundenbuch 1, no. 19, 23-25. All royal charters given to Chur will be cited according to this edition, abbreviated as BUB 1; cf. R. Kaiser, Autonomie, Integration, bilateraler Vertrag; Kaiser, Churrätien im frühen Mittelalter, 247 and 275-276; Id., Capitula Remedii, 146-181; Siems, Recht in Rätien.

18 Fichtenau, Urkundenwesen, 38-53; Erhart und Kleindinst, Urkundenlandschaft Rätien, 83-90; Bullimore, Folcwin of Rankweil; Erhart, Erratische Blöcke; Innes, Practices of property; Kleindinst, Folcwin Archiv.

19 BUB 1, no. 63*, ed. Meyer-Marthaler and Perret, 55-56: "quod ipsi et praedecessores eorum reges Francorum memoratum populum sub plenissima tuitione mundeburdo atque defensione constitutum semper habuisset, ita ut nullus exteriorem po[t]entes et propinquos eorum nec etiam ipsos iniustas leges et consuetudines inponere debuissent". 
the Alemans and Romans should settle the dispute "according to Roman law «. ${ }^{20}$ So there appears to be plenty of evidence that Roman law continued to be the prevalent legal system in 10th-century Raetia. But it needs to be emphasized that besides Roman law, the legal tradition of this region included a number of further texts and practices, such as ecclesiastical law, royal charters and capitularies preserved in Raetian manuscripts and, of course, orally transmitted legal custom. ${ }^{21}$ Practically, this meant that only local people with legal knowledge could know how one had to proceed in a given situation, and the rulers had an interest in ensuring that this continued to be the case by granting a certain degree of autonomy. ${ }^{22}$

In the following study, an attempt will be made to analyse the political and social background of processes of decentralization that took place in Churraetia in the course of the 10th century. As will be demonstrated, institutional modes and legal devices rooted in late Roman fiscal administration played an important role in the transformation of this region. Moreover, as will be shown, we can also observe an important legal change which must be analysed against the backdrop of an important legacy of Carolingian rule in the Alpine regions, namely ethnically defined legal pluralism.

\section{The Delegation of Fiscal Rights to the Episcopal Church of Chur in the Mid-10th Century}

Legal culture underlines Roman continuity or a deliberate affirmation of Romanness in early medieval Churraetia, but it only points to a major phenomenon. It seems that late Roman state structures also lingered on or continued to exercise significant influence on the political culture of Churraetia, such as the transalpine road system and other infrastructures and resources related to it. ${ }^{23}$ In particular, the famous "Churrätische Reichsurbar «, ${ }^{24}$ probably compiled in connection with the division of the Carolingian Empire in the Treaty of Verdun of $843,{ }^{25}$ illustrates the importance of fiscal structures and local administration, which to some extent appear to have followed Roman models, as has been shown in a more recent study by Sebastian Grüninger on the royal seigneurie of Churraetia. ${ }^{26}$

It is well known that in late Roman financial administration land-registers and lists of people liable to poll-tax played an important part. ${ }^{27} \mathrm{~A}$ late-Roman law ordering the production of registers or inventories of property that was confiscated and thus entered fiscal administration shows remarkable parallels to the structure of early medieval polyptychs and

20 BUB 1, No. 96, ed. Meyer-Marthaler and Perret, 78-80; see also below, n. 95. The application of Roman law seems to be justified by the fact that both the abbey under dispute and the bishop of Chur as defendant were from Raetia. See Gaupp, Die germanischen Ansiedlungen, 252-253.

21 See the contributions in Eisenhut et al., Schrift, Schriftgebrauch und Textsorten: Grüninger, Stratigraphie, Struktur und Text; Siems, Zur Lex Romana Curiensis.

22 Kaiser, Autonomie, Integration, bilateraler Vertrag.

23 Clavadetscher, Verkehrsorganisation in Rätien; recently Heitmeier, Verkehrsorganisation und Infrastruktur.

24 Kleindinst, Churrätische Reichsguturbar.

25 Clavadetscher, Churrätische Reichsguturbar als Quelle.

26 Grüninger, Grundherrschaft im frühmittelalterlichen Churrätien.

27 See in detail Zuckerman, Du village à l'Empire. 
registers of both fiscal and ecclesiastical property. ${ }^{28}$ Carolingian rulers, beginning with Pippin I and Charlemagne, repeatedly ordered registers and lists of such property and of revenues and corvées related to them to be written down on the basis of an interrogation (inquisitio) carried out among the local tenants. ${ }^{29}$ That ecclesiastical property was also ordered to be registered had to do with the fact that to a large extent ecclesiastical property originated in royal munificence, meaning that it was once fiscal property and in the rulers' perspective continued to be regarded as fiscal property in functional terms, despite the fact that it had been irrevocably transferred to individual churches and monasteries. With the famous polyptych of St Germain-des-Prés compiled in the late 820s and the polyptychs of the abbeys of Prüm in the Eifel region and Werden in the Ruhr area, most likely written down as a reaction to Viking incursions and depradations, we have several lengthy registers illustrating how large Carolingian monasteries administered their property and income and managed their workforce; to those one may add a large number of smaller registers and fragments showing how widespread this phenomenon was. ${ }^{30}$

Against this backdrop, what makes the Churrätische Reichsurbar so unique is the fact that it contains a fiscal register that was apparently produced before the pieces of property listed therein were transferred to and thus came into permanent use of the church. Indeed, the very occasion to which its compilation has been attributed, 842/843 points to the preparations made in the wake of the Treaty of Verdun, when the division of the Carolingian Empire among the sons of Louis the Pious caused a major survey to be produced that, at least in some respects, resembles the Domesday Survey of 1086. ${ }^{31}$ Each of Louis's sons was to have an equal share in fiscal property, income etc., and several other fragments of registers seem to have originated in the historical situation of $842 / 843 .{ }^{32}$ This explains why the Churrätische Urbar does make references to several churches and monasteries, but in its basic structure is firmly grounded in terms of secular administration, as may be illustrated by the entry for the "Drusus Valley" ("Drusentalgau«), a district situated in the northern part of Churraetia and containing in its very name a reference to Drusus, Augustus' stepson, who had conquered these regions shortly before the turn of the eras. ${ }^{33}$ It starts with a title that was added later and is thus placed in brackets here:

28 Codex Theodosianus 9.42.7 (published in 369), ed. Mommsen and Meyer, 510:: "Si quis intra provinciam [...] stilum proscriptionis incurrerit, per ordinarii officii sollicitudinem bonorum eius [...] plena descriptio conprehendat, quod spatium et quod sit ruris ingenium, quid aut cultum sit aut colatur, quid in vineis olivis aratoriis pascuis silvis fuerit inventum, quae etiam gratia et quae amoenitas sit locorum, quis aedificiis ac possessionibus ornatus, quotve mancipia in praediis occupatis vel urbana vel rustica vel quarum artium generibus inbuta teneantur, quot sint casarii vel coloni, quot boum exercitiis terrarum atque vomeribus inservientium, quot pecorum et armentorum greges et in qua diversitate numerati sint, quantum auri et argenti, vestium ac monilium vel in specie vel in pondere et in quibus speciebus quidve in enthecis sit repertum. Tum demum omnia ea [...] inquisitione constricta rationalis rei privatae tradantur officio nostro nectenda patrimonio. Mox vero ad nos sub litteris publicis iudicis singillatim de omnibus nominatimque referatur [...] post factam a praedicto officio investigationem rationalis rei privatae, cui inquisitio secunda mandata est Theodosiani libri« (= Cod. Iust. IX, 49; see also Cod. Theod. 9.42.3, issued in 357).

29 Kuchenbuch, Verrechtlichung von Erinnerung; Heidrich, Befragung durch Beauftragte; see also Esders, Römischen Wurzeln.

30 Editions: Das Prümer Urbar, ed. Schwab; Urbare der Abtei Werden a. d. Ruhr, ed. Kötzschke, 4-87; Kuchenbuch, Ordnungsverhalten im grundherrlichen Schriftgut; Id., Abschied von der »Grundherrschaft«.

31 Davis, Domesday Book; Percival, Precursors of Domesday.

32 Clavadetscher, Churrätische Reichsguturbar and Metz, Kloster Weißenburg.

33 Erhart, Das Drusental. 
$<\S$ Property rights of the church of Chur $>$

$<\S$ District in the name of the Drusen valley $>$

In the villa of Bludenz: a church with a tithe from this villa. And the tithe of Bürs along with the church. This church has 20 acres (iugera) of land. And of meadows 30 cart-loads (carratae) [of grass]. One hide. This has been a benefice which Fero had. Donatus holds there 7 acres (iugera).

The tax (census) of this district (ministerium), however, that is the Drusus Valley, is as follows: In each zelga [= a third of the arable lands of a homestead] they have to cultivate (arare) 70 acres (iugera) and stack it up most cautiously (cum omni cautela) in the royal granary (in dominicum horreum). Of iron (ferrum), 70 bars (massae), each by ... Of honey (mel), 70 measures (mensuare), each ... Of piglets (frisginga), 7 each worthy of 10 denarii. This is the royal tax-income (census regis).

For the officeholder (minister), that is the "sheriff" (sculthacius): 6 bars (massae) of iron (ferrum). Hatchets (secures) 5. Six piglets (friskinga), each worthy of 6 denarii. Of corn (granum), 35 bushels (modii). 12 bushels (modii) of crop. 14 bushels (modii) of oat (avena). [There are] 6 farmsteads (mansiones), which render 12 piglets (friskinga) each, worthy of 8 denarii, [and] 12 cheese-loaves (formatici). Whenever the officeholder (minister) goes to war (in hostem), they have to render one good horse (caballus honestus). And they also render further support (aliud adiutorium).

There is, however, another royal tax-income (census regis), from the district (ministerium) called Ferraires. It is such custom (consuetudo) that each man (omnis homo) who is working there in ore mining (pro ferro) (with the exception of Wanzo's family) renders the sixth part to the king (in dominico). Accordingly, there are 8 smelting furnaces (fornaces) there.

To the "sheriff (sculthacius) [have to be given] 36 bars (massae), whenever he holds his judical assembly (placitum) there. Whenever he does not, [he gets] 32 [and] 8 hatchets (secures) [and] 8 goatskins (pelles hircinae).

In this district (ministerium) 3 fishponds (piscinae) are held.

This is what we found (invenimus) in this district (ministerium). ${ }^{34}$

While this entry in the register reveals in its very last line (invenimus) that it resulted from an official inquiry, it is interesting to see how much it was focused on renders and revenues to be extracted, while a list of properties, and corvées, are lacking. The renders listed refer to special regional or indeed local conditions, as they not only include certain amounts of agricultural produce, but also finished pieces of metalwork, based on the exploitation of the mines and the use of furnaces attached to them. It is in this context that reference is made to a certain orally transmitted custom (consuetudo), which was now apparently written down for the first time.

$34 »<\mathcal{S}$ Curiensis ecclesiae propietatis iura $><\mathcal{\S}$ Ministerium in pago vallis Drusianae. $>$ In villa Pludono ecclesia cum decima de ipsa villa. Et decima cum ecclesia de terra iugere.XX. De pratis carratas .XXX. hobam .I. Hoc fuit beneficium, quod habuit Fero. Habet ibi Donatus iugera.VII. Census autem huius ministerii, id est vallis Drusianae, iste est: In unaquaque zelga debent arare.LXX. iugera atque ea cum omni cautela in dominicum horreum congregare. De ferro.LXX. massas, unaquaque per .... De melle.LXX. mensuras, unaquaque .... Frisgingas.VII. unaquaque .X. denarios valentes. Iste est census regis. Ministro autem, id est sculthacio. Sex massas de ferro. Secures.V. Sex friskingas, unaquaque.VI. denarios valentes. De grano .XXXV. modios. .XII. modios des frumento. .XIIII. modios de avena. Mansiones in ministerio VI. quae reddunt fiskingas.XII. unaquaque.VIII. denarios valentes. formaticos.XII. Quando in hostem perget minister, reddere debent unum caballum honestum. Etiam si aliud adiutorium reddunt. Est autem alius census regis, de ministerio, quod dicitur Ferraires. Est ergo talis consuetudo, ut omnis homo, qui ibi pro ferro laborat (extra Wanzaningam genealogiam) sextam partem reddat in dominico. Sunt ergo ibi octo fornaces. Sculthacio vero massas.XXXVI., quando suum placitum ibi habet. Quando autem non habet.XXXII. secures.VIII. pelles hircinas.VIII. Habentur ergo in ministerio piscinae .III. Haec invenimus in isto ministerio. [...] $<\xi$ Ministerium in Planis $>$ [...] Sculdhazii census iste est: De isto ministerio libram .I. Haec invenimus in isto ministerio«: BUB 1, ed. Meyer-Marthaler and Perret, 380-381 and 388-389. 
While two churches with their tithes are registered at the beginning, the core part of this entry deals with the census of the king and that of the centenarius (called sculthacius here). ${ }^{35}$ This is perhaps the text's most interesting feature as it clearly shows a certain tranche of fiscal income that was directly attributed to the king's local office-holder. The famous Folcwin, attested only twenty years before the inventory was listed, had been centenarius in Rankweil in the Drusus Valley. ${ }^{36}$ The register's entry thus seems to echo the administrative practice in use when he was in office. The centenarii or sculdais were governing districts that were not identical with the location of fiscal property, but have to be seen as a rank within a hierarchy of military office-holding between counts and decans once adopted from the Roman military. ${ }^{37}$ In Churraetia, however, their position became territorialized, meaning that they were in charge of a certain local district in which they exercised important military, judicial and fiscal functions. ${ }^{38}$ While they were most likely responsible for collecting all revenues for the king, the register clearly shows that they had a special share in these revenues exclusively reserved for them and their office, separate from the royal tax (census regis). The sculdhazii census did not include grain and piglets alone, but also bars of iron and hatches or axes, made of iron quarried in the local mines and processed further. Thus, it seems the centenarius was somehow officially involved in the exploitation of the mines in Churraetia. ${ }^{39}$

The Reichsurbar therefore shows that at this time large parts of tax income and pieces of land (enumerated in other entries) were not yet in the hand of churches and monasteries, as we find in other regions of the Frankish Empire, ${ }^{40}$ but handled by secular officials. At the same time, a summary given at very end of the register references the income of the king (census regis) from Churraetia by combining the entries from all districts to be paid in solidi to the royal chamber. ${ }^{41}$ This clearly indicates that the renders in kind were expected to be commuted into cash at a certain stage, as the king was mainly interested in filling his treasury, while placing the local administration in the hands of counts and centenarii.

Now it is interesting to see that the Reichsurbar, which came down to us only in a late 15th- or early 16 th-century copy made by the humanist scholar Aegidius Tschudi, ${ }^{42}$ apparently came into the hands of the episcopal church of Chur at some time. Most historians have assumed for good reason that this most likely took place in the 1oth century. Indeed, it is well known that Churraetia came to play an important role for the Ottonian rulers once they became interested in Italy. ${ }^{43}$ In was in this context that Otto I transmitted fiscal revenues of Churraetia to the episcopal church of Chur in 951 along with other rights that had pertained to the county of Chur before, as is documented by an extant charter: ${ }^{44}$

On the terminology of office-holding, see Krug, Untersuchungen.

36 See above, n. 32.

37 On the centenarii and sculdais see Murray, From Roman to Frankish Gaul, 73: »The term centenarius was not an isolated borrowing from the late Empire. The Merovingian hierarchy of dux, comes, tribunus, and centenarius was a system of ranks and offices adopted as a whole from the Roman military by the Franks and adapted to the conditions of the Merovingian kingdom in Gaul.«

38 Esders, Amt und Bann.

39 Kleindinst, Das churrätische Reichsguturbar, 97-99 and 105-106.

40 See the studies by Reinhold Kaiser quoted above in n. 3, 12, and 21.

41 BUB 1, ed. Meyer-Marthaler and Perret, 393-394.

42 St. Gallen, Stiftsbibliothek, cod. 609. See Grüninger, Grundherrschaft im frühmittelalterlichen Churrätien, 163.

43 Clavadetscher, Herrschaftsbildung in Rätien, 330.

44 BUB 1, nos. 108 and 119, ed. Meyer-Marthaler and Perret. 
[Chrismon]: In the name of the holy and indivisible Trinity. Otto, by divine clemency, king of the Franks and the Italians. Let it be known to the devotion of all faithful men, of the holy church of God and ours, both present and future, that we, on consultation and intervention of our beloved son Liudolf, and especially for love of God and for the remedy of our soul, have by this precept of ours, as we can do it justly and lawfully, conceded, given and offered to the holy church of the mother of God Mary and the blessed confessor of Christ Lucius, which is the capital of the episcopacy of Chur, presided over by Bishop Hartbert, our fidelis:

In the county (comitatus) of the above-mentioned duke of Raetia [= Swabia] the whole fisc (omnem fiscum) of the very county (comitatus) of Chur, as it had belonged until now to the royal chamber and authority (ad regale pertinebat cameram et postestatem) along with the just coercive power to use the inquest with regard to this fisc (cum districtione iusta ad eundem fiscum inquirendum), as it was previously determined that for our service and right was to be inquired from our tenants (veluti prius ad nostrum opus et ius a quadrariis inquirendum fuerat constitutum), with full integrity and lawful inquest, we transfer and delegate everything from all our right and ownership into the right and ownership of the above-mentioned church, so that it will have and possess it in eternity. For this reason, we prescribe and order that henceforth no high or low person of our kingdom shall dare to disturb the before-mentioned church and its representative. However, if someone turns out as violator of this precept, he shall know that he will have to pay 100 pounds of pure gold, one half to our chamber and the other to the above-mentioned church. And so that this precept will be trusted more truly and observed more attentively, we gave order for it to be signed by our hand through our seal ring.

+ The mark (signum) of Lord Otto, the most serene king. [monogram]

$+\mathrm{I}$, the chancellor Wigfried, have attested, in place of Bruno the archchaplain. [impressed seal]

Given on the Idus of October, in the 951st year of our lord Jesus Christ's incarnation, in the 9th indiction, in the 16th year of King Otto's rule in Francia, his first [year of king] in Italy. Done in Pavia; in the name of God, happily, Amen. ${ }^{45}$

45 "In nomine sanctae et individue trinitatis. Otto dei gratia rex Francorum et Italicorum. Omnium sanctae dei ecclesiae fidelium nostrorumque presentium scilicet ac futurorum noverit devotio, qualiter nos consultu atque interventu Liudolfi dilecti filii nostri precipueque dei amore nostręque anime remedio per hoc nostrum preceptum prout iuste et legaliter possumus, concedimus, donamus atque offerimus eclesię sancte dei genetricis Marię beatique Lucii confessoris Christi que est caput Curiensis episcopii, cui preest venerabilis episcopus [Ha]r[t]bert[us noste]r fidelis, in comitatu predicti ducis Recia omnem fiscum de ipso Curiense comi[ta]tu, sicuti actenus ad regale pertinebat cameram et postestatem, cum districtione iusta ad eundem fiscum inquirendum, veluti prius ad nostrum opus et ius a quadrariis inquirendum fuerat constitutum, cum omni integritate ac legitima inquisicione, omnia et ex omnibus a nostro iure et dominio in predicte eclesię ius et dominium omnino transfundimus et delegamus, ut habeat in perpetuumque possideat. Precipientes itaque iubemus ut nulla regni nostri magna parvaque persona pretaxat[a]m [ec]l[e]sia[m] eiusque vicarium inde inquietare presumat. [Si quis au]tem huius precepti violator estiterit, sciat se compositurum auri optimi libras centum, medietatem camera nostre et medietatem predicte eclesię. Et ut hoc preceptum verius credatur et attentius observetur, manu nostra insignitum anulo nostro iussimus adsignari. Signum domni Ottonis serenissimi regis. Uuigfridus cancellarius advice Brunonis archicapellani recognovi. Data idus octobris, anno incarnationis domini nostri Iesu Christi DCCCCLI, indictione VIIII, anno domni Ottonis regis in Francia XVI, in Italia I; actum Papiae; feliciter in dei nomine amen «: BUB 1, no. 108, ed. Meyer-Marthaler and Perret. See also RI I.3.3 n. 2200, in: Regesta Imperii Online. Accessed on 10 June 2019: www.regesta-imperii.de/id/0951-10-15_1_0_1_3_3_768_2200. 
The immediate political situation in which this generous grant was made was caused by the sudden death of King Lothar II of Italy in November $950 .{ }^{46}$ Berengar of Ivrea took the crown shortly afterwards and in order to prevent his widow Adelheid from entering a new marriage and thereby making her new husband heir to the kingdom of Italy, he had her captured. In this situation Otto, whose first wife had died shortly before and who was befriended by Adelheid's brother, the king of Burgundy, seems to have developed plans to intervene in Italy and liberate her. Already in summer 951 his son Liudolf, Duke of Swabia, marched into northern Italy, which was seen as documenting an early stage of the rivalry that would lead to Liudolf's insurrection against his father in 953. At this stage, however, relations seem to have been peaceful, and it was on Liudolf's intervention as duke of Swabia that Otto granted the fiscal income to the bishop of Chur. The immediate background to this was the marriage of Otto, who had captured Pavia in September 951, with Adelheid of Burgundy in October, while his assumption of the title rex Francorum et Italicorum is, in fact, attested for the first time in the charter for Chur, issued on the 15th October. ${ }^{47}$ As Otto's transfer of fiscal rights to Bishop Hartbert of Chur, who had accompanied him to Pavia, ${ }^{48}$ was motivated by the expectation that having access to Italy would be of continuous importance for Otto, this could indeed be imagined as a perfect occasion to hand over a fiscal register, or parts of it, to the bishop. ${ }^{49}$ The reference to omnis fiscus, whatever this may have meant precisely, attributes some plausibility to such a hypothesis. ${ }^{50}$ From the 950 s we have several further charters which show how much both Raetia itself, and being on good terms with the bishop of Chur, must have mattered to Otto and his advisers. ${ }^{51}$ He now transformed the right to collect tolls, which had already been granted to the bishop of Chur, into perpetual ownership, and donated to him in compensation for losses the church of Chur had suffered from Saracen incursions (quia loca ad eandem aecclesiam pertinentia ab Italia redeundo 1 invasione Sarazenorum destructa ipsi experimento didicimus) a royal curtis in Zizers, located in the upper Rhine valley only 10 miles north of Chur along the transalpine road to Italy..$^{52}$ And in 958 , he also gave to the bishop of Chur half of the city of Chur (dimidiam partem ipsius civitatis cum tali districtione et iure sicuti hactenus ad nostram pertinebat potestatem) along with all the tribute paid by free men in this province (homines ipsius totius provinciae censuales ac liberi debitores), as well as the right to mint coins. ${ }^{53}$ This process of delegating more and more fiscal rights to the episcopal church came to an end with a long charter issued in 960, in which Otto also gave the royal household at Chur, his curtis, to the bishop of Chur:

46 See the surveys by Beumann, Ottonen, 67-72; Althoff, Königsherrschaft ohne Staat, 96-101; Keller, Ottonen, 36-41.

47 On the background to this charter, Otto's new royal title and the notary who wrote the charter, see Huschner, Transalpine Kommunikation, 96-97, 205, 297, also emphasizing the year 951/952 as a turning point for Ottonian politics with regard to Italy.

48 Kaiser, Churrätien im frühen Mittelalter, 121.

49 Grüninger, Grundherrschaft im frühmittelalterlichen Churrätien, 183; Id., Stratigraphie, Struktur und Text, 234.

50 See the discussion in Kaiser, Churrätien im frühen Mittelalter, 121-122.

51 Otto also issued charters to restore disputed distant property of the Chur bishopric located in Alsace: BUB 1, no. 111 (952) and 112 (953), ed. Meyer-Marthaler and Perret. On the importance of these acts, see Kaiser, Churrätien im frühen Mittelalter, 114 .

52 BUB 1, no. 109 (952), ed. Meyer-Marthaler and Perret; BUB 1, no. 113 (955), ed. Meyer-Marthaler and Perret; confirmed and detailed in the following year: no. 114. See Kaiser, Churrätien im frühen Mittelalter, 115 and 120-121.

53 BUB 1, no. 115 (958), ed. Meyer-Marthaler and Perret. See Kaiser, Churrätien im frühen Mittelalter, 122. 
While also approving the request of the aforementioned bishop as sound, and after having consulted our fideles, we have given into ownership the piece of property in question [...] in turn in the county of Raetia our royal household called Chur (Curia curtem nostram regalem nominatam), which our count of this place Adalbert had held from us until now as a benefice, also the Bergell Valley with all coercive rights of judicial assembly and ban which had belonged until now to the county (cum omni districtione placiti et panni hactenus ad comitatum pertinentis), but also the taxes of all [future] acquisition (totius inquisitionis census) on the mountains and the plain fields and woods belonging to this march, and also the toll that used to be paid by all travelling merchants in that valley (teloneum in ipsa valle ab iterantibus emptoribus persolvi consuetum), which was paid recently in the same place of Chur, and also the complete tax of the hundred and the "sheriff's district " (censum omnem ab ipsa centena et scultatia Curiensi) from sheep's pasture and the coerced procuratorship of falcons (procuratione bannita falchonum) and the military tax (hostisana), with total acquisition of the full tax and ban from the bridge (cum tota inquisitione integri census et banni de ponte) and all selling at this place (omni venditione ipsius loci) and the complete tax revenue of the free men (totumque exactum a liberis hominibus), from the tenants [paying the fourth part] and taxable properties on the mountains and plains and the peasants on the mountains (sive a quartanis ac terris censualibus in montanis et planis et colonis montanaricis), and also the church located in the castle Bonaduz [and Rhäzüns] with their tithes and everything which belongs ecclesiastically to the same bishopric, in such way, that the aforementioned bishop and all later administrators of this bishopric [have] the household in question with everything justly and lawfully belonging to it, households, small households, buildings, slaves of both sex, peasants and all vassals from the mountains, as they always used to do service for the household in question under the count and his father, and all farmsteads, those which have been given as a benefice and those who served directly to the royal household, with the [parts of the] Alps and all vineyards (with exception of two in Trimmis with two vintners, residents and forests, both surrounded with the usual ban district cincture), arable lands, meadows, willows, stagnant and running waters, mills, fishing grounds, revenues and dues, cultivated and non-cultivated, acquired and yet to be acquired ... ${ }^{54}$

54 "... Nos quoque precatum praenominati pontificis congruum approbantes consultu fidelium nostrorum eandem quam nobis in concambium exhibuit praefatae [aecclesie proprietatem ab ipso recipiens, econtra in com] ]itatu Rehciae in vico Curia curtem nostram regalem nominatam quam comes noster ipsius loci Adalbertus in beneficium hactenus a nobis obtinuit, vallem quoque Pergalliae cum omni districtione placiti et panni hactenus ad comitatum pertinentis, sed et totius inquisitionis census sive in montibus et planis campis et silvis ad ipsam marcham pertinentibus nec non et teloneum in ipsa valle ab iterantibus emptoribus persolvi consuetum, modo vero in eodem loco Curia datum, censum quoque omnem ab ipsa centena et scultatia Curiensi de pastu ovino et procuratione bannita falchonum et de hostisana cum tota inquisitione integri census et banni de ponte et omni venditione ipsius loci totumque exactum a liberis hominibus sive a quartanis ac terris censualibus in montanis et planis et colonis montanaricis, aecclesiam videlicet in castello Beneduces [et Ruzunnes] rs cum suis decimis ac omnibus sibi aecclesiastice pertinentibus ad idem episcopiurn in proprium contradidimus, ea scilicet ratione quatenus praedictus episcopus omnesque in posterum ipsius episcopii provisores omnia praenominata ipsamque curtem regalem cum omnibus ad eandem iuste et legaliter pertinentibus, curtibus curtilibus aedificiis mancipiis utriusque sexus colonis et vassellariis cunctis de montanis, sicut semper ad ipsam curtem serviebant sub ipso comite et patre eius et omnibus mansis, sive sint in beneficium date sive serviant ad curtem dominicam, cum alpibus et vineis omnibus, exceptis duabus in Trimune cum vinitoribus duobus et accolis et forestis, cinctis duabus cum consueta cinctionis districta, agris pratis pascuis aquis aquarumque desursibus molendinis et fundis piscationibus exitibus et reditibus cultis et incultis quesitis et inquirendis": BUB 1, no. 119, ed. Meyer-Marthaler and Perret, 98-100, a. 960. The formula enumerating the rights and incomes pertinent to the location at the end of the passage quoted is damaged in the original charter. 
As is made clear in its first part (not quoted here), the charter was motivated by an exchange of locations bringing Otto into possession of the place of Kirchheim located in the Neckargau (Swabia), while the king in turn granted the rights and holdings of Chur to Bishop Hartbert of Chur, whose crucial role in the territorial expansion and acquisition of the episcopal church of Chur can hardly be underestimated..$^{55}$ One gets the impression that Otto now almost completely donated to the bishop of Chur the remaining fiscal rights and pieces of fiscal property located in this region and until then belonging to the ius regium. ${ }^{56}$ Indeed, Reinhold Kaiser rightly emphasized that what was now given to the bishop of Chur were basically the fiscal rights that had, since Late Antiquity, belonged to the provincial governor (praeses) of Churraetia. ${ }^{57}$ To this one may add former imperial property located within Churraetia. Both had come into the possessions of the Frankish kings and counts. Otto's grant of 960, as well as giving the royal curtis, ${ }^{58}$ included certain rights pertaining to the county (comitatus), the census of the centena as already mentioned in the Reichsurbar, the military tax (hostisana) $)^{59}$ to be paid in compensation for not doing service by the :free men" (liberi homines), several types of ban, tolls and income etc. It seems that the military organization was also passed over to the bishop to rearrange it according to what seemed necessary. And indeed, in the famous Indiculus loricatorum of 981, a list of an additional contingent of mounted troops to be furnished for Otto II's campaign in southern Italy, the bishop of Chur is listed as obliged to contribute 40 »knights " to the Ottonian army. ${ }^{60}$

So we may assume that the process of delegating fiscal rights to the bishop of Chur was completed by 960, while Otto would be crowned emperor in $962 .{ }^{61}$ Taking into account the growing importance of transalpine connections, Otto thought that this would be an effective means to integrate the episcopal church into military organization and logistic administration for intensifying communication with Italy. However, it would be too simple to assume that the process of the delegation of fiscal rights only started in the mid-10th century and was exclusively motivated by Otto I resuming Carolingian imperial policies connected to Italy. This sounds far too radical and too schematic. For the process by which the episcopal church of Chur acquired rights from secular rulers extended over more than a century and took place in different stages. In fact, the episcopal church of Chur enjoyed immunity by a grant given by Louis the Pious in $831 .{ }^{62}$ The privileges granted by Otto I mark the end of this development rather than its beginnings.

55 Kaiser, Churrätien im frühen Mittelalter, 116 and 120-121 (on Hartbert's personal background).

56 Kaiser, Churrätien im frühen Mittelalter, 125-126: "Mit der Übernahme des Königshofes im vicus von Chur ... dürfte der Bischof im Stadt- und Stadtumlandgebiet sämtliche Herrschaftsrechte, die bisher noch dem König bzw. Grafen zustanden, übernommen haben ... Das war das erste Mal, dass im ottonischen Reich ein Bischof expressis verbis die gräfliche Gerichtsbarkeit erhielt."

57 Kaiser, Churrätien im frühen Mittelalter, 127.

58 Kaiser, Churrätien im frühen Mittelalter, 115-116.

59 Clavadetscher, Hostisana und pretium comitis, whose interpretation seems a bit outdated now. See Grüninger, Grundherrschaft im frühmittelalterlichen Churrätien, 270 (no. 218) and 482.

60 Indiculus loricatorum (a. 981), ed. Weiland, No. 436, 633. For a discussion of this important document, see Auer, Kriegsdienst des Klerus; and in particular Werner, Heeresorganisation und Kriegführung.

61 On the delegation of fiscal rights to the bishop of Chur, see also Kaiser, Churrätien im frühen Mittelalter, 125-126.

62 BUB 1, no. 54, ed. Meyer-Marthaler and Perret, 45-46. 


\section{Legal Plurality and Change around 900}

What one needs to explain is why Otto and his advisers were willing to place so much trust in the bishop of Chur. To understand this, one has to take into account several further steps that took place between the draft of the Reichsurbar in 842 and the transfer of all fiscal rights to the bishopric in 951. In what follows, I will isolate a crucial moment, which, in my view, for the first time led in this direction, occurring in the early 1oth century and going hand in hand with a profound legal change. At the centre of the following discussion is an original diploma that Conrad I, the first East Frankish king who was not a Carolingian, issued for Bishop Theodulf of Chur and which is preserved as an original: ${ }^{63}$

[Chrismon]: In the name of the holy and indivisible Trinity. Conrad, by the favour of divine clemency, king. Let it be known to the wisdom of all our faithful men, both present and future, that Theodulf the venerable prelate of the church of Chur came to our Clemency, bemoaning the fact that he was unable, without royal assistance, to correct numerous acts of neglect and violence (negligentiae ac violentiae) which were being done in his bishopric. Having therefore taken the counsel of our faithful men, that is, Salomon the venerable bishop [of Constance], Erchanger the count of the palace, Perahtold, Conrad, Henry, and other noble men (nobiles viri) serving us, together with the testimony of the leading men (primores) of Chur and upon their truthful counsel, we found that [he] ought to conduct an inquisition by oaths (sacramentis investigare) upon any doubtful matters (dubia quaeque). Therefore, if any acts of violence (violentiae) should be carried out in the villages (villulae) subjected to the holy church of Chur, in its lands, meadows, woods, [among its] slaves (servis), female-slaves (ancillis), or [its] affairs of any kind (quibuscumque negotiis), by the request (rogatu) of the aforementioned nobles (proceres), we grant to the same venerable bishop Theodulf and to his successors the power and the license, according to the custom (mos) of other prelates, to conduct an inquisition by oaths (sacramentis investigare) upon any hidden matters (latentia quaeque). We also desire and command that no slave (servus) or female-slave (ancilla) belonging to the same church of Chur should hereafter presume to free themselves by a thirty-year period (se per tricennia tempora liberare), as formerly, so we have heard, they were doing, by a bad custom (mala consuetudo) and at variance with [slaves] of other churches, so that rather if such as these might chance to be discovered, by our royal authority let them be compelled to act as slaves (servire). We have also ordered this charter (praeceptum) to be drawn up (conscribi), by means of which we will and firmly decree, that all abiding in the same bishopric should be useful to the aforementioned bishop Theodulf and to his successors and should be obedient in all righteous affairs (in omnibus iustis negotiis), and that none should presume to contradict (contradicere) him. And so that this charter (praeceptum) should endure, firm and stable, we have signed it below with our own hand, and we have commanded it to be sealed with the impression of our ring. 
+ The mark (signum) of Lord Conrad <Signed monogram $>$ the most serene king +

+ I Salomon the chancellor attest, in place of Pilgrim the arch-chaplain $<$ Sign of recognition $><$ Impressed seal $>$

Given on the seventh calends of October [Sept 25] in the year of the incarnation of the lord 912, in the first indiction, and in the first year of the reign of the most glorious king Conrad I. Done at Bodman palace; in the name of God, happily, Amen. ${ }^{64}$

The charter was granted by Conrad in September 912 when he visited the royal palace at Bodman on the northern shore of Lake Constance. Its date of issuing thus belongs to a period of transition after the Eastern branch of the Carolingian dynasty had died out the year before ${ }^{65}$ As a consequence, a great deal of negotiation took place between various political actors, as the new ruler Conrad I was interested in enhancing his legitimacy as the first non-Carolingian king. It is in this difficult situation, full of tension, that we can observe the forging of new alliances, but also substantive legal change. Much that had been regarded as law by tradition and custom now came under close scrutiny and was adjusted in the context of new personal constellations and power structures. Conrad's charter for Chur begins in its narrative part by relating that Bishop Theodulf of Chur had approached the king saying that many acts of negligence and violence were being committed within his episcopacy (multae negligentiae ac violentiae in suo episcopate fierent) which he felt unable to correct without royal help (quae sine regali adiutorio corrigere nequivisset). The king thus had this matter discussed, as we learn, with his fideles; that is Bishop Salomon of Constance, the Count of the Palace Erchanger, and with Bertold, Conrad, Henry and the remaining noblemen, and also some magnates from Chur, who were referred to as primores in this context. With the help of these primores' advice and veracious testimony, they decided that there were some dubious matters that should be henceforth investigated under oath. To make this possible, King Conrad granted to the bishop of Chur the right to conduct inquisition procedure - that is, deciding a case by compulsorily requiring a sworn testimony from the local population -

64 "In nomine sanctae et individuae trinitatis. Chuonradus divina favente clementia rex. Noverit omnium fidelium nostrorum praesentium scilicet et futurorum sagacitas, qualiter venerabilis Diotolfus Curiensis aecclesiae praesul ad nostrum clementiam venit, reclamans se quod multae negligentiae ac violentiae in suo episcopate fierent quae sine regali adiutorio corrigere nequivisset. Initoque igitur consilio nostrorum fidelium, Salomonis scilicet venerabilis episcopi, Erchangarii comitis palatii, Perahtoldi, Chuonradi, Heinrici cęterorum nobelium vi[r]orum nobis assistentium nec non primorum Curiensium testimonio et veraci consilio eorum invenimus dubia quaeque sacramentis investigare debere. Igitur si aliquae violentiae in villulis sanctae Curiensi aecclesiae subiectis terris pratis silvis servis ancillis vel quibuscumque negotiis inlatae fuerint, rogatu suprascriptorum procerum eidem venerabili Diotolfo episcopo suisque successoribus potestatem ac licentiam secundum morem cęterorum praesulum latentia quaeque sacramentis popu[li] investigare donamus. Volumus quoque atque praecipimus, ut nullus servorum vel ancillarum ad eandem Curiensem aecclesiam pertinentium se per tricennia tempora liberare deinceps audeat, sicuti hactenus ut audivimus mala consuetudine et dissimili aliarum aecclesiarum fecerant, quin potius sicubi tales forte reperiuntur, nostr[a re]gali auctoritate servire compellantur. Iussimus quoque hoc praeceptum inde cons[cribi] per quod volumus firmiterque iubemus, ut cuncti in eodem episcopio consistentes praefato Diotolfo episcopo suisque successoribus adiuvantes et in omnibus iustis negotiis obedientes existant et nullus ei contradicere audeat. Et ut hoc praeceptum firmum stabileque permaneat, manu nostra subtus illud firmavimus anulique nostri impressione insigniri praecepimus. Signum domni Chuonradi serenissimi regis. Salomon cancellarius advicem Piligrimi archicapellani recognovi et ... Data VII. Kl. Oct. anno incarnationis domini DCCCCXII, indictione I; anno vero regni gloriosissimi regis Chuonradi I; actum Potamico palatio; in dei nomine feliciter amen «: BUB 1, no. 91, ed. Meyer-Marthaler and Perret; translated by Shane Bobrycki. I would like to thank Shane Bobrycki for allowing me to quote from his translation he kindly produced after the Vienna conference. An image of the charter can be found in Kaiser, Churrätien im frühen Mittelalter, 119, no. 22.

65 See in general Goetz, Konrad I. 
whenever somebody acted violently against the lands and dependents of the villages belonging to the episcopal church of Chur. Moreover, Conrad also prescribed that no male or female slave (nullus servorum vel ancillarum) of the episcopal church of Chur could henceforth obtain freedom through the time-span of thirty years, as the king had heard that some people had done so following "a custom which is bad and different from those of other churches" (mala consuetudine et dissimili aliarum aecclesiarum). If henceforth such slaves were found, they should be compelled to perform their servile duties by royal authority. The charter's dispositive section closes by admonishing that all inhabitants of the episcopatus of Chur should henceforth support Bishop Theodulf and his successors and not act disobediently or be resistant. At the document's end, we find the king's subscription by his signum, as the charter was confirmed and also validated by Bishop Salomon of Constance, who did so on behalf of Archchaplain Pilgrim of Salzburg presiding over the royal chancery.

If we take a closer look at the charter's two main provisions, it becomes clear that the inquisition procedure granted here as a procedural right to the bishop of Chur was a legal device that Frankish kings had begun to concede to selected episcopal churches and monasteries since Louis the Pious. ${ }^{66}$ It was based on the idea that compulsory testimony may be obtained through an oath that can be required from the local population so that they either had to denounce certain misdeeds or that they had to provide testimony on some matters on which the person entitled to carry out the inquisition procedure would question them. The whole procedure puts the plaintiff of a case into a strong position, as it is basically in cases of public interest that inquisition procedure was carried out, not in what we call "private law«, where other modes of proof (a party's testimony or oath, ordeal etc.) were commonly used. ${ }^{67}$ It stems from Roman procedure in fiscal law and can be traced back even into the late Roman republic. It was adopted by the Frankish kings already in the Merovingian period, and the Carolingian innovation was indeed that this right to conduct inquisition procedure, usually reserved for the king and his missi to protect fiscal property, now became delegated individually to selected ecclesiastical institutions to apply it to church property, which was regarded as "public " ${ }^{68}$ as it derived to a large extent from fiscal property granted by kings to churches and monasteries, but came to be regarded as inalienable. ${ }^{69}$ So what the bishop of Chur obtained here through Conrad's privilege was basically what several other bishops and abbots had obtained before by grants of immunity ${ }^{70}$ - such as the abbot of the neighboring monastery of St Gall, to whom the right of inquisition procedure by compulsory oath (iuramentum coactum) had been granted and confirmed in 853, 873, 903 and indeed shortly before Conrad I's charter for Chur, by the same ruler in March 912. ${ }^{71}$ The Ottonian rulers would follow this policy by issuing charters granting the right of inquisition procedure. ${ }^{72}$

66 The classic study on Carolingian inquisitio is Brunner, Zeugen- und Inquisitionsbeweis, extended version in Id., Forschungen zur Geschichte, 88-247; see also Esders, Römischen Wurzeln. On inquisition procedure granted to individual churches and monasteries from Louis the Pious onward, see Mischke, Kapitularienrecht und Urkundenpraxis, 57-62.

67 Brunner, Zeugen- und Inquisitionsbeweis.

68 Esders, Römischen Wurzeln.

69 Esders and Patzold, Justinian to Louis the Pious.

70 Bachrach, Immunities as tools of royal military policy.

71 BUB 1, no. 85 (891) and 90 (912), ed. Meyer-Marthaler and Perret; Ganahl, Studien zur Verfassungsgeschichte, 53-54.

72 Bachrach, Inquisitio as a tool of royal governance. 
The second topic dealt with in Conrad's charter for Chur, the prescription period of thirty years ${ }^{73}$ that could allow a slave to obtain freedom, was also a legal institute of Roman law, which can be traced back into the early 5 th century AD. ${ }^{74}$ In 419 , the West Roman emperor Honorius had published a law on the thirty-years rule of prescription, which he wanted to be applied to coloni that his free tenants fixed to the soil of large estates. ${ }^{75}$ This and a second law on the longi temporis praescriptio ${ }^{76}$ were selected for the Theodosian Code published in 438. And in a lengthy novel of 449 the Western emperor Valentinian III sought to establish even retroactively the term of thirty years as a general rule for the settlement of all kinds of disputes in order to provide "profound peace for the human race", since no one can "endure that suits shall be instituted which grandfathers and great-grand-fathers did not know about ". ${ }^{77}$ As a consequence, it was stated that "no action shall hereafter be brought after a period of thirty years in regard to persons of an ignoble birth status, whether coloni, inquilini, or slaves of either sex, and in regard to peculia and the offspring of the above designated, ownership, that is, a perpetual, patrimonial, emphyteutic, or municipal ownership. ${ }^{78}$ This type of rule eased the process for coloni and slaves to get rid of their master or possessor and obtain freedom for themselves and their offspring or to look for a new master. It is noteworthy, however, that in Valentinian's law the church is not yet mentioned, while Justinian would legislate on the use of prescription in favour of the church. ${ }^{79}$

These regulations on coloni, including coloni on fiscal property, and servi were maintained in Churraetia ${ }^{80}$ as becomes evident from the 8th-century Lex Romana Curiensis, although with a post-Roman specification: if such coloni or slaves took refuge in churches, they could not be reclaimed by their master after the time span of thirty years had elapsed. ${ }^{81}$ So, by this time, it was the ecclesiastical institutions that took profit from adopting this ruling from late Roman law.

It is interesting to see that this issue was handled very differently already in the Carolingian period, as is quite typical for Carolingian legal pluralism. This can be illustrated using a capitulary most likely issued by Charlemagne for Italy: Jones, Later Roman Empire, 799-800; Nörr, Entstehung; Piekenbrock, Befristung, Verjährung, Verschweigung, 44-81 and 317-346.

75 C. Th. 5.18 (De inquilinis et colonis) 1 (419): Theodosiani libri, vol. 1, ed. Mommsen and Meyer, $239-240$.

76 C. Th. 4.14 (De actionibus certo tempore finiendis), 1 (424): Theodosiani libri, vol. 1, ed. Mommsen and Meyer, $194-196$.

77 Novella Valentiniani 3.27 (De triginta annorum praescriptione omnibus causis opponenda): Theodosiani libri, vol. 2, ed. Mommsen and Meyer, 122-126. Translation taken from: Pharr, Theodosian Code and Novels, 538-539.

78 Theodosiani libri, vol. 2, ed. Mommsen and Meyer, 122-126. "De originariis et coloniis, inquilinis ac servis utriusque sexus, peculiis atque agnationibus designati iuris, id est perpetui patrimonialis enfyteuticarii et rei publicae, post triginta annorum curricula nulla deinceps actio moveatur. Et negotium, de quo per expressa tempora sollemniter nemo pulsavit, novum nemo proponat. " Translation taken from Pharr, Theodosian Code and Novels, 538-539.

79 Kaiser, Zur hundertjährigen Verjährung.

80 On the role of unfree people in Raetia see Niederstätter, Zur Frage der Unterschichten.

81 Lex Romana Curiensis 18.11, ed. Meyer-Marthaler, 396: "Originarios vero vel servos, qui ad honorem ecclesiasticum adspiraverint, debere intra triginta annos a dominis revocari. Ita tamen, ut diaconus pro se vicarium, si habuerit, reddat, et omne peculium suum dominus eius usurpet. Quod si vicarium non habuerit, unde reddat, ipse ad conditionem propriam revocetur». 
"Wherever in Italy a fugitive slave of the king, the church or another man is detected, he can be reclaimed by his master without any prescription of years, provided that the master is a Frank, an Aleman or of any another nation. If, however, the master is a Lombard or a Roman, he shall either acquire or lose his slaves according to their law, as has been fixed among them in ancient times. ${ }^{82}$

From this passage it becomes clear that in Italy only Roman and Lombard law continued to follow the Roman thirty years prescription rule which they applied to fugitive slaves, while according to Frankish, Aleman or Bavarian law this principle was not accepted at all. The application of this rule can be vividly demonstrated by charters. For instance, in a lawsuit from northern Italy from the first half of the 8th century, a man whose freedom was disputed was given the opportunity to prove according to Lombard law that he had been living as a free man for more than thirty years. ${ }^{83}$ However, in Carolingian Italy this rule should not be applied to a Frank or Aleman who came to settle in Italy following the Frankish conquest of Lombard Italy: according to the principle of personality of law ${ }^{84}$ he could claim that if it was this slave, the case would have to be decided according to his law of birth. Ethnically defined legal pluralism could thus have profound consequences on the legal status of an unfree person. ${ }^{85}$ But, so it seems, Lothar I had already suspended the thirty-years rule for Italy in a capitulary given in Pavia in $832 .{ }^{86}$ The situation in Raetia was apparently not affected by this. It thus was only Conrad I in his charter of 912, who followed the interest of the episcopal church of Chur by introducing a departure from Roman legal tradition. This becomes clear as the thirty-years rule as applied in favour of slaves is branded as "a custom which is bad and different from those of other churches" (mala consuetudine et dissimili aliarum aecclesiarum).

In fact, Louis the Pious in a capitulary of 829 had already prescribed that, in analogy with the procedure to be used for fiscal property inquisition, the procedure should be used in cases in which the thirty-years rule was brought into action against ecclesiastical property. ${ }^{87}$ This illustrates that the two provisions given in the charter of 912 were already conceived as connected to one another in the Carolingian period. But it is not clear whether these regulations were actually put into effect, for the issue was apparently hotly debated in 829 , while

82 Capitularia regum Francorum 1, no. 98, ed. Boretius, 206, c. 8: "De servis fugacibus. Ubicumque intra Italiam sive regius sive ecclesiasticus vel cuiuslibet alterius hominis servus fugitivus inventus fuerit, a domino suo sine ulla annorum praescriptionum vindicetur; ea tamen ratione, si dominus Francus sive Alamannus aut alterius cuiuslibet nationis sit; si vero Langobardus aut Romanus fuerit, ea lege servos suos vel adquirat vel amittat, sicut inter eos antiquitus est constituta".

83 Carte di famiglia, no. 4, ed. Gasparri and La Rocca, 312-314 (= Chartae Latinae Antiquiores XXVIII, No. 847); see Feller, Sulla libertà personale, 197-200, and Rio, Slavery after Rome, 84-85.

84 Guterman, Principle; Hoppenbrouwers, Leges nationum.

85 In the legislation of Louis the Pious the thirty-years rule appears to have been adopted from the Epitome Aegidii: Capitula de praescriptione temporis, ed. Boretius and Krause, Capitularia regum Francorum 2, no. 195, 25-26; see also Regino of Prüm, De synodalibus causis, 1.22.

86 Capitularia regum Francorum 2, no. 201, ed. Boretius and Krause, 62, c. 12: „Ut per trigenta annos servus liber fieri non possit, si pater illius servus aut mater illius ancilla fuerit. Similiter de aldionibus."

87 Capitulary of Worms a. 829, c. 8, ed. Boretius and Krause, Capitularia regum Francorum 2, 13:»Ut de rebus ecclesiarum, quae ab eis per triginta annorum spatium sine ulla interpellatione possessae sunt, testimonia non recipiantur, sed eo modo contineantur, sicut res ad fiscum dominicum pertinentes contineri solent.« 
from this period the first charters come into existence that confer the right to inquisition procedure to individual monasteries and churches. ${ }^{88}$ This rather suggests that Louis' general rule of 829 was not universally applied, but only put into effect sporadically by individual grants; the same seems to hold true for Lothar's provision given in $\mathbf{8 3 2}$ for Italy.

To understand Conrad I's approach to dealing with custom, it is helpful to look closer at the historical situation when he issued his charter. It seems likely that the precedent, the "custom of other churches", to which the charter refers was introduced by Salomon, bishop of Constance and abbot of St Gall. Salomon plays a prominent role in the charter as royal adviser and as chancellor, and he had a broad legal expertise, as becomes evident from a collection of formulae from St Gall attributed to him. ${ }^{89}$ St Gall, by contrast, has a long series of royal privileges dating back to the later 9th century, immunity grants, the right to carry out inquisition procedure etc. that allowed St Gall to enjoy special legal regulations to keep its ecclesiastical familia together. ${ }^{90}$ Salomon of St Gall and Constance played an important part in the entourage of Conrad I and appears as his most important adviser at this time..$^{91}$ He had been chancellor since 909 under Louis the Child, the last East Frankish king from Carolingian stock. ${ }^{92}$ The charter was issued in September 912, shortly after Raetia had become somehow involved in the nebulous process of the formation of the Duchy of Swabia. ${ }^{93}$ In fact, only the year before, in 911, Burchard, the first duke of Swabia since 909, who belonged to an important Swabian noble family and was also in charge of Raetia, had revolted against the comes palatii Erchanger and against Bishop Salomon of Constance, who was also abbot of St Gall, both being loyal supporters of Conrad I at that time. At an assembly held in Swabia, Burchard was charged with treason and executed in November 911 along with his brother Adalbert, Count of Thurgau, while Burchard's son, Burchard II, was exiled to Italy. ${ }^{94}$ As Conrad was only elected king on the 10th of November by Swabian and Saxon nobles at Forchheim, ${ }^{95}$ Burchard's deposition and execution appears directly connected to Conrad's election. The position of the duke of Swabia - possibly only a principatus under Burchard I - does not seem to have been replaced after Burchard's death, meaning that Conrad kept this region under his direct control. At the time when his charter for Chur was drafted, King Conrad appears to have relied very much on the authority of Salomon, who had already served his predecessor. It thus seems clear that Salomon must have played an important role in Burchard's deposition and execution. Indeed, as becomes clear from a later dispute heard at Rankweil in 920 about the abbey of Pfäfers, which had once belonged to Burchard I, but was

88 Mischke, Kapitularienrecht und Urkundenpraxis, 57-62.

89 See for discussion Rio, Legal Practice and the Written Word, 152 and 156-157.

90 Ganahl, Studien zur Verfassungsgeschichte, 26-70.

91 Postel, Nobiscum partiri. Konrad I.

92 Frank, Ostfränkische Reichskirche.

93 Zotz, König Konrad I.

94 Excellent discussion of the contradictory evidence and possible reconstructions of events and background is given by Zettler, Geschichte des Herzogtums Schwaben, 78-82, and Zotz, König Konrad I., 192-197.

95 Annales Alamannici a. 912: Lendi, Untersuchungen zur frühalemannischen Annalistik, 188. On Conrad's itinerary in the years 911/912, as far it can be reconstructed from his charters, see Goetz, Letzte »Karolinger«?, 73-75 with a helpful map. 
transferred to Salomon under Louis the Child in 905, the conflict between Salomon, bishop of Constance and abbot of St Gall since 890, and Burchard, who must have been a powerful figure shortly after 900, must have had wider implications. ${ }^{96}$ In King Conrad's charter of 912 reference is made, among others, to Erchanger and his brother Berthold, two Swabian nobles from the Alaholfing family, who were sympathetic to Conrad at this point. ${ }^{97}$ However, in 913/14 Burchard II returned from Italy and tried to capture the property confiscated from his father following his execution in 911. It seems that Erchanger and Berthold changed sides soon afterwards and joined Burchard II's rebellion against King Conrad. Apparently, Erchanger had himself acclaimed as duke of Swabia near Bodman in $915 .{ }^{98}$ Along with his brother Berthold he entered into a feud with Salomon of Constance / St Gall at this time or shortly before, even holding the latter captive for some time. ${ }^{99}$ Through the intervention of King Conrad, Salomon was released while Erchanger was sentenced on a charge of treason to monastic exile at a synod assembled at Hohenaltheim in Swabia along with his brother Berthold, but was executed on order of King Conrad in $917 .{ }^{100}$ So the charter was issued at an early stage of a profound and bloodstained reversal of Swabian aristocratic networks, with the bishop of Constance and abbot of St Gall being firmly on Conrad's side. In particular, the execution of the first duke of Swabia in 911 must have caused considerable unrest resulting in encroachments upon property belonging to the episcopal church of Chur. ${ }^{101}$

What needs to be asked is why the topic of thirty-year prescription became so important in this situation that some desired to have it abolished by a royal charter. Naturally, this rule was also applied occasionally in other regions and periods, but what one needs to explain is why it apparently became so important in quantitative terms in early 10th-century Churraetia that it prompted a royal decree in favour of the bishop of Chur. In 912, the problem of unfree people leaving their ecclesiastical lord must have acquired a substantial dimension in Churraetia, meaning that unfree dependents attempted to get rid of their ecclesiastical lord on quite a large scale. If the thirty-year rule could become such an important legal device for unfree ecclesiastical servants, this means that the episcopal church of Chur must have found it difficult to establish an overview of the total number of its unfree dependents over the last thirty years or so; moreover, regular occasions on which the dependency of an unfree person was made visible must have become very rare since c. 880 , if we calculate the thirty years backwards. And while we may assume that the validity of the bonds of such dependence often relied on custom more than on written documentation, it seems reasonable to assume that unfree dependents did not "automatically" seek to get rid of their bond once

96 BUB 1, no. 96, ed. Meyer-Marthaler and Perret, 78-80. On the background, see Erhart, Kirchlicher Besitz, 126 and 129-131, who observed an attempt by St Gall to extend its influence over Raetian territory.

97 On Erchanger, see Maurer, Herzog von Schwaben, 37-48; Zotz, Erchanger; Zettler, Geschichte des Herzogtums Schwaben, 77-78 and 82-93.

98 Annales Alamannici a. 915: Lendi, Untersuchungen zur frühalemannischen Annalistik, 198.

99 Annales Sangallenses maiores a. 914/15: Henking, Annalistischen Aufzeichnungen des Klosters St. Gallen, 280; Ekkehard of St Gall, Casus S. Galli, 15-21, ed. Haefele, 42-56.

100 Hellmann, Synode von Hohenaltheim, 132-133.

101 It should be noted that some property the episcopal church of Chur wanted to protect may have been situated at some distance from Churraetia in Alsace, as this came into dispute again later. Vollrath, Rechtstexte, 329-332. 
this seemed possible. If we want to explain why this caused a problem of notable quantity, a scenario has to be imagined in which it actually made sense for many unfree peasants to quit their ecclesiastical lord in early 10th-century Churraetia. It thus seems tempting to link such a phase of profound insecurity and loosening of social bonds, which seems to have extended over more than thirty years, to turmoil and political fragmentation during the decomposition of the East Frankish kingdom in the later years of the reign of Charles the Fat and following his deposition and death in $887 / 888 .^{102}$ As Brigitte Kasten has shown, in the early 10thcentury East Frankish kingdom there were fierce struggles for material resources, while many manorial documents originated in this situation, as an attempt to protect ecclesiastical property. ${ }^{103}$ If such an assumption is correct, the execution of Duke Burchard of Swabia in 911 gains additional weight, for it seems entirely conceivable that he and his supporters used his judicial power as duke of Raetia to alienate unfree dependents of the episcopal church of Chur by simply applying the thirty-years prescription rule of Roman law. Although such a charge is hard to prove, it seems more likely than assuming that this flight of unfree servants happened only after his death. Following the duke's deposition, and taking advantage of a situation when there was no duke of Swabia, while important ecclesiastical advisers such as Salomon of Constance and St Gall increased their influence at court, the bishop of Chur must have seen a chance to revoke the release of fugitive dependents who had fled his church in the preceding years. However, as they had apparently based their claim for freedom on a well-known regulation of Roman law, the application of existing law would not have helped Theodulf of Chur to pursue his objective.

This leads us to the topic of legal change. It is noteworthy that nothing in Conrad's charter of 912 suggests that we are dealing here with Roman law. On the other hand, from the Lex Romana Curiensis it becomes clear that the lex tricennalis was well known, as was the fact that it derived from Roman law. Moreover, we even have several bits from Carolingian capitularies that refer to the lex tricennalis, ${ }^{104}$ but these mostly deal with the possibility that the church might acquire property and serfs through prescription. Consequently, the intention of the clause in the charter cannot have been to brand Roman law in any general way as bad or old fashioned. Only a certain aspect of Roman law was meant to be branded as bad, in as much as it contradicted the interests of the episcopal church of Chur. The Frankish Church, of course, regarded itself as an institution that lived according to Roman law, as we already find expressed in the 7th-century Ribuarian law code: ecclesia vivit lege Romana. ${ }^{105}$ But this was not what was at stake here. The predominance of Roman law in Raetia apparently made it possible that slaves who had not been required for service by their lord for 30 years could go to a public court and claim freedom for themselves or protection by a new master who promised them better conditions of service. Apparently, the bishop of Chur wanted to have this legal loophole closed and to adopt for his church a legal regulation that was already enjoyed by several other churches and monasteries.

102 Keller, Zum Sturz Karls III. See in more detail MacLean, Kingship and Politics, 123-198.

103 Kasten, Kampf um die wirtschaftlichen Ressourcen.

104 See above, n. 81,85 and 86.

105 Fürst, Ecclesia vivit lege Romana?

medieval worlds • No. $10 \cdot 2019 \cdot 17-45$ 
At first sight there seems to be some irony in the fact that the ancient law of the slaveholding Roman society, in allowing the acquisition of freedom by prescription, appears as more friendly towards slaves than the law which the Frankish kings conferred to ecclesiastical institutions via privilege. On closer inspection, however, it becomes apparent that the legal situation was far more complicated than one might expect, for there were several different legal traditions, with the one fixed by the Lex Romana Curiensis being only one, albeit important, among them. It tells us even more that the charter not only brands the thirty-years rule as a bad custom, but as one that differs from the custom enjoyed by other churches. In the case of St Gall this also had to do with the fact that St Gall, though located only 50 miles north of Chur, was situated in a region subject to Aleman law, where jurisdiction was held by the Aleman duke; as we saw, within Aleman law, the thirty-years rule was rejected. ${ }^{106}$ Moreover, St Gall had acquired its right to conduct inquisition procedure by a royal privilege, ${ }^{107}$ and this apparently served as the model for the bishop of Chur.

Another aspect which seems relevant here for departing from Roman tradition and which made things even more complicated is that since the late 5 th century, church property came to be regarded as inalienable in legal terms. ${ }^{108}$ Practically, this meant that even according to Roman law the legal situation was not clear: for in this sense, a slave who obtained freedom for himself caused a diminution of church property, and this could be used as an overriding principle to deny any slave the right to obtain freedom through prescription. The rulings on this principle, in particular those established by the East Roman emperor Justinian, became accessible in Francia only in the earlier 9th century through the Epitome Iuliani, from where it was copied into the capitulary collection of Ansegis of Fontenelle. ${ }^{109}$

So there was a plurality of legal traditions and legal texts that could contradict one another, and it is against this backdrop that a royal privilege could prioritize certain competing norms over others. Therefore, the bishop of Chur could approach the king and ask him to decide, as there was a conflict of contradictory laws and regulations - in fact of conflicting Roman laws (that is the Theodosian code on prescription vs. Justinian's novels on church property) and Alemannic law, while other churches and monasteries enjoyed special regulations and two capitularies had suspended the thirty-year rule in favour of slaves. King Conrad followed Bishop Theodulf's suggestion and issued this charter, which, in fact, assimilated the status of the episcopal church of Chur to that of the neighbouring monastery of St Gall. Thus, by royal privilege, the differences between various leges barbarorum and Roman law were pushed aside, while the grant of procedural rights typical for fiscal property and the idea that the inalienability of church property constituted an overriding principle, which was at the heart of a process that transformed the episcopal church of Chur into an ecclesiastical principality. ${ }^{110}$

106 See above, n. 81.

107 See above, n. 70 .

108 Esders, Frühmittelalterliche »Blüte« des Tauschgeschäfts; Calvet-Marcadé, Assassin des pauvres.

109 See Esders and Patzold, Justinian to Louis the Pious, 389-395. On knowledge of the Epitome Iuliani in St Gall as documented by manuscripts and excerpts, see Kaiser, Epitome Iuliani, 37-39, 219-223, 421-423.

110 Clavadetscher, Herrschaftsbildung in Rätien. 
A final remark on legal change in this period of transition as documented by Conrad I's diploma relates to the detestation of the thirty-years rule in favour of slaves as »bad custom « (mala consuetudo). As is well known, custom is usually treated as a good thing in law, certainly as a subsidiary or supplementary body of regulations, but often also having a worth of its own. ${ }^{111}$ 66 years ago the French historian Jean-François Lemarignier, an expert on the development of "la société féodale", wrote an important article on the disappearance of Carolingian administrative structures and the emergence of local custom entitled $» L a$ dislocation du pagus et le problème des consuetudines". Imagining the creation of new legal structures in the course of the late 10th and the 11th century, Lemarignier observed a diminution of royal authority giving rise to the seigneurie, a process he saw, in line with many historians before him, encapsulated in the granting of immunities. ${ }^{112}$ As royal privileges of immunities conferred the rights of ban and other rights, by undermining the authority of the local office-holder, usually the count, they effectively led to the evolution of local customary law within ecclesiastical principalities or seigneuries. The rights conferred upon an immunist, especially his entitlement to exercise jurisdiction and to collect a variety of fines and revenues resulting from his performing justice, from raising tolls, from collecting renders etc. now came to be called consuetudines, customs. More recently, on the occasion of the bicentenary of the French revolution, the late Christian Lauranson-Rosaz, interpreted this new term »bad customs", malae consuetudines, as arising from basically the same process at a second stage. ${ }^{113}$ The end of the Frankish fisc, which he assumed for the 1oth century, but also the end of the domanial system, »la seigneurie foncière", which he saw increasingly replaced by the "seigneure banale", the entitlement to exercise certain functions independently from property, were, in Lauranson-Rosaz', view at the heart of a process which eventually led to a widespread abuse of these powers. Justice was performed when some income and revenues could be gained. It was the corruption of the judicial system that linked this development to the early peace of God movement which also made a claim for some sort of judicial reform and sought to replace malae consuetudines through royal legal acts and through convenientiae (as bonae consuetudines). ${ }^{114}$ In French scholarship, the debate on bad customs (malae consuetudines) has always been closely linked to that on the révolution féodale or mutation de l'an mil. ${ }^{115}$

However, Conrad I's charter with its reference to mala consuetudo was written almost a century earlier. The idea of disqualifying customs as bad was certainly older, ${ }^{116}$ but what is striking here is its appearance in a legal document. The charter of 912 suggests that the appearance of the term "bad custom « in a legal document should not be linked to the feudal revolution. Rather, it happened in a period of transition and rapid change, which appears to be shaky and perilous also in the sense that it could easily introduce legal change according to the interests of powerful magnates. For this reason, the early 10th century appears as a

111 See the classic study by Kern, Recht und Verfassung. On Kern and his ideas, see now Liebrecht, Fritz Kern.

112 Lemarignier, La dislocation du pagus.

113 Lauranson-Rosaz, Mauvaises coutumes d’Auvergne; Id., »Mauvaises coutumes« aux »bonnes coutumes«; see also Magnou-Nortier, Mauvaises coutumes.

114 See the discussion by Mazel, Féodalités, 184-191 and West, Reframing the Feudal Revolution, 184-187. See also Kosto, Making Agreements in Medieval Catalonia.

115 White, Bad customs (malae consuetudines). For Italy see Nobili, Malae consuetudines in Lungiana.

116 On different notions of custom, see most recently Kerneis, Le droit et la coutume.

medieval worlds • No. $10 \cdot 2019 \cdot 17-45$ 
fight over the notion and validity of custom. The question of which customs were actually "bad" and which not, depended on the viewpoint, of course. But the very rhetoric suggests that many of the developments we can already observe in the early 10th century were, in fact, hardly peaceful and harmonious and must be placed in a wider perspective by looking backward.

Charlemagne had warranted lex et consuetudo for Churraetia in 772 , as did Lothar I in 843. ${ }^{117}$ However, Charlemagne's son, Pippin of Italy, prescribed in a capitulary:

"It was our wish to insert the following: Where there is written law (lex), it shall prevail over custom (consuetudo), and no custom (consuetudo) shall be placed above the written law $(l e x){ }^{118}$

This seems to echo the late-Roman idea that a custom which did not interfere with the public welfare may be regarded as law ${ }^{119}$ - if Carolingian legislation was legitimized with reference to utilitas publica such an interpretation does not appear to be too far-fetched. However, in the late Carolingian period, when Carolingian rulers ceased to issue capitularies, and when written documentation became reduced to some extent, this must have caused a re-evaluation of custom. For precisely this reason, custom needed to be checked. Re-thinking custom led to its re-evaluation according to different criteria. ${ }^{120}$ It seems particularly noteworthy in the case of Churraetia that the notion of a »bad custom « was extended here to a legal tradition that was clearly rooted in written law. This points to a new legal reasoning. Legal change was introduced through royal privilege, by individual grants, but had an impact on many people nonetheless. So it was not only the case that in the absence of clear administrative or legal structures, the past and its uses gained importance, but also that action in the present often drew authority and legitimacy from claims about the past. It was the past itself, custom, oral and written, that needed to be checked, historicized, reaffirmed or delegitimized.

117 See above, n. 16 and 18 .

118 Pippini capitulare ca. 790, c. 10, ed. Boretius, Capitularia regum Francorum 1, no. 95, 201: "Placuit nobis inserere: ubi lex est, praecellat consuetudinem, et nulla consuetudo superponatur legi.«. See also Magnou-Nortier, Lex et consuetudo. 119 C. Th. 5.20.1, Interpretatio: "Longa consuetudo, quae utilitatibus publicis non inpedit, pro lege servabitur". Theodosiani libri, vol. 1, ed. Mommsen and Meyer, 242.

120 Vollrath, Herrschaft und Genossenschaft, 54. 


\section{References}

Abbreviations

MGH = Monumenta Germaniae Historica

Althoff, Gerd, Die Ottonen. Königsherrschaft ohne Staat (Stuttgart, 2000).

Bachrach, David S., Immunities as tools of royal military policy under the Carolingian and Ottonian kings, Zeitschrift der Savigny-Stiftung für Rechtsgeschichte. Germanistische Abteilung 130 (2013) 1-36.

Bachrach, David S., Inquisitio as a tool of royal governance under the Carolingian and Ottonian kings, Zeitschrift der Savigny-Stiftung für Rechtsgeschichte. Germanistische Abteilung 133 (2016) 1-80.

Beumann, Helmut, Die Ottonen (Stuttgart, 1997).

Brunner, Heinrich, Zeugen- und Inquisitionsbeweis der karolingischen Zeit (1865), extended version, in: Heinrich Brunner, Forschungen zur Geschichte des deutschen und französischen Rechts. Gesammelte Aufsätze (Weimar, 1894) 88-247.

BUB 1 = Bündner Urkundenbuch, ed. by Elisabeth Meyer-Marthaler and Franz Perret, vol. 1: 390-1199 (Chur, 1955).

Bullimore, Katherine, Folcwin of Rankweil. The world of a Carolingian local official, Early Medieval Europe 13 (2005) 43-77.

Calvet-Marcadé, Gaëlle, Assassin des pauvres. L'Église et l'inaliénabilité des terres à l'époque carolingienne (Turnhout, 2018).

Capitularia regum Francorum 1, ed. Alfred Boretius, MGH Capit., vol. 1 (Hanover, 1883).

Capitularia regum Francorum 2, ed. Alfred Boretius and Viktor Krause, MGH Capit., vol. 2 (Berlin, 1897).

Carte di famiglia. Strategie, rappresentazione e memoria del gruppo familaire di Totone di Campione (721-877), ed. Stefano Gasparri and Christina La Rocca (Rome, 2005).

Codex Theodosianus, ed. Theodor Mommsen and Paul M. Meyer, vol. 1 (Berlin, 1905).

Constitutiones et acta publica imperatorum et regum inde ab a. DCCCCXI usque ad a. MCXCVII (911-1197), ed. Ludwig Weiland, MGH Const. 1 (Hanover, 1893).

Clavadetscher, Otto P., Das churrätische Reichsguturbar als Quelle zur Geschichte des Vertrags von Verdun (1953), in: Otto P. Clavadetscher, Rätien im Mittelalter. Verfassung, Verkehr, Recht, Notariat. Ausgewählte Aufsätze (Disentis, 1994) 114-176.

Clavadetscher, Otto P., Hostisana und pretium comitis. Ein Beitrag zur Reichsgutforschung (1964), in: Otto P. Clavadetscher, Rätien im Mittelalter. Verfassung, Verkehr, Recht, Notariat. Ausgewählte Aufsätze (Disentis, 1994)187-196.

Clavadetscher, Otto P., Verkehrsorganisation in Rätien zur Karolingerzeit (1955), in: Otto P. Clavadetscher, Rätien im Mittelalter. Verfassung, Verkehr, Recht, Notariat. Ausgewählte Aufsätze (Disentis, 1994) 270-299.

Davis, Ralph H. C., Domesday Book. Continental parallels, in: James Clarke Holt (ed.), Domesday Studies. Papers Read at the Novocentenary Conference of the Royal Historical Society and the Institute of British Geographers Winchester 1986 (Woodbridge, 1987) 15-39.

Ekkehard von St. Gallen, Klostergeschichten, ed. and trans. (into German) Hans H. Haefele (fourth edition), (Darmstadt, 2002).

Epitome Aegidii: Capitula de praescriptione temporis, in: Capitularia regum Francorum 2, ed. Alfred Boretius and Viktor Krause, no. 195 (Berlin, 1897) 25-26. 
Erhart, Peter (ed.), Das Drusental. Der Walgau und das Vorderland im frühen Mittelalter (Nenzing, 2009).

Erhart, Peter, Erratische Blöcke am Alpennordrand? Die rätischen Urkunden und ihre Überlieferung, in: Peter Erhart, Karl Heidecker and Bernhard Zeller (eds.), Die Privaturkunden der Karolingerzeit (Dietikon-Zürich, 2009) 161-172.

Erhart, Peter, Kirchlicher Besitz, in: Peter Erhart (ed.), Das Drusental. Der Walgau und das Vorderland im frühen Mittelalter (Nenzing, 2009) 113-138.

Erhart, Peter and Julia Kleindinst, Urkundenlandschaft Rätien (Vienna, 2004).

Esders, Stefan, Amt und Bann. Weltliche Funktionsträger (centenarii, vicarii) als Teil ländlicher Gesellschaften im Karolingerreich, in: Thomas Kohl, Steffen Patzold and Bernhard Zeller (eds.), Kleine Welten. Ländliche Gesellschaften im Karolingerreich (Ostfildern, 2019) 255-307.

Esders, Stefan, Die frühmittelalterliche "Blüte« des Tauschgeschäfts. Folge ökonomischer Entwicklung oder Resultat rechtspolitischer Setzung?, in: Irmgard Fees and Philippe Depreux (eds.), Tauschgeschäft und Tauschurkunde vom 8. bis zum 12. Jahrhundert / L'acte d'échange, du VIIIe au XIIe siècle (Cologne, 2013) 19-44.

Esders, Stefan, Procopius of Caesarea, the lex tricennalis, and the »time of the Vandals«. Historiography, law, and political debate in mid 6th-century Constantinople, Early Medieval Europe 27 (2019) 195-225.

Esders, Stefan, Roman law as an identity marker in post-Roman Gaul (5th-9th centuries), in: Walter Pohl, Clemens Gantner, Cinzia Grifoni and Marianne Pollheimer-Mohaupt (eds.), Transformations of Romanness in the Early Middle Ages. Regions and Identities (Berlin, 2018) 325-344.

Esders, Stefan, Die römischen Wurzeln der karolingischen inquisitio in Fiskalsachen, in: Claude Gauvard (ed.), L'enquête au moyen âge (Rome, 2008) 13-28.

Esders, Stefan, Der Verjährungstitel des Liber iudiciorum (L.Vis. X, 2) und die politischen Implikationen des Ersitzungsgedankens im Westgotenreich, in: Ignacio Czeguhn, Cosima Möller, José Antonio Pérez Juan and Yolanda Quesada Morillas (eds.), Wasser - Wege Wissen. Eine Annäherung an das Studium der Wasserkultur von der römischen Antike bis zur islamischen Zeit / Agua, vías, conocimientos en la Península Ibérica. Una aproximación al estudio de la cultura del agua desde la antigüedad romana hasta la época musulmana, (BadenBaden, 2018) 57-86.

Esders, Stefan and Gunnar Folke Schuppert, Mittelalterliches Regieren in der Moderne oder Modernes Regieren im Mittelalter? (Baden-Baden, 2015).

Esders, Stefan and Steffen Patzold, From Justinian to Louis the Pious. Inalienability of church property and the sovereignty of a ruler in the ninth century, in: Rob Meens, Dorine van Espelo, Bram van den Hoven van Genderen, Janneke Raaijmakers, Irene van Renswoude and Carine van Rhijn (eds.), Religious Franks. Religion and power in the Frankish kingdoms. Studies in honour of Mayke de Jong (Manchester, 2016) 371-392.

Feller, Laurent, Sulla libertà personale nell'VIII secolo: I dipendenti dei Totoni, in: Stefano Gasparri and Christina La Rocca (eds.), Carte di famiglia. Strategie, rappresentazione e memoria del gruppo familaire di Totone di Campione (721-877) (Rome, 2005) 179-207.

Fichtenau, Heinrich, Das Urkundenwesen in Österreich vom 8. bis zum frühen 13. Jahrhundert (Vienna, 1971).

Fleckenstein, Josef, Die Hofkapelle der deutschen Könige, 2 vols. (Stuttgart, 1959/1966).

Frank, Thomas, Die ostfränkische Reichskirche zur Zeit Ludwigs des Kindes, in: Klaus Herbers and Bernhard Vogel (eds.), Ludwig das Kind (90o-911) (Forchheim, 2002) 67-83. 
Fürst, Carl Gerold, Ecclesia vivit lege Romana?, Zeitschrift der Savigny-Stiftung für Rechtsgeschichte. Kanonistische Abteilung 61 (1975) 17-36.

Ganahl, Karl Hans, Studien zur Verfassungsgeschichte der Klosterherrschaft St. Gallen von den Anfängen bis ins hohe Mittelalter (Innsbruck, 1931).

Gaupp, Ernst Theodor, Die germanischen Ansiedlungen und Landtheilungen in den Provinzen des römischen Westreiches in ihrer völkerrechtlichen Eigenthümlichkeit und mit Rücksicht aufverwandte Erscheinungen der alten Welt und des späteren Mittelalters dargestellt (Breslau, 1844; repr. Aalen, 1962) 252-253.

Goetz, Hans-Werner (ed.), Konrad I. Auf dem Weg zum »Deutschen Reich«? (Bochum, 2006).

Goetz, Hans-Werner, Der letzte "Karolinger«? Die Regierung Konrads I. im Spiegel seiner Urkunden, Archiv für Diplomatik 12 (1980) 56-125.

Grüninger, Sebastian, Grundherrschaft im frühmittelalterlichen Churrätien. Ländliche Herrschaftsformen, Personenverbände und Wirtschaftsstrukturen zwischen Forschungsmodellen und regionaler Quellenbasis (Chur, 2006).

Grüninger, Sebastian, Stratigraphie, Struktur und Text des Churrätischen Reichsguturbars. Streifzüge durch die "Geologie« eines frühmittelalterlichen Güterverzeichnisses, in: Heidi Eisenhut, Karin Fuchs, Martin Hannes Graf and Hannes Steiner (eds.), Schrift, Schriftgebrauch und Textsorten im frühmittelalterlichen Churrätien (Basel, 2008) 222-249.

Guterman, Simeon L., The Principle of the Personality of Law in the Germanic Kingdoms of Western Europe from the Fifth to the Eleventh Century (New York, 1990).

Halm, Heinz, Das Reich des Mahdi. Der Aufstieg der Fatimiden (875-973) (Munich, 1991).

Heidrich, Ingrid, Befragung durch Beauftragte - Beeidung durch Betroffene. Zum Verfahren bei mittelalterlichen Besitzaufzeichnungen, Vierteljahrschrift für Sozial- und Wirtschaftsgeschichte 85 (1998) 352-358.

Heitmeier, Irmtraut, Verkehrsorganisation und Infrastruktur an alpinen Passstraßen im frühen Mittelalter, in: Christian Later, Michaela Helmbrecht and Ursina JecklinTischhauser (eds.), Infrastruktur und Distribution zwischen Antike und Mittelalter (Hamburg, 2015) 7-36.

Hellmann, Ernst, Die Synode von Hohenaltheim (916), Historisches Jahrbuch 73 (1954) 127-142.

Henking Karl, Die annalistischen Aufzeichnungen des Klosters St. Gallen (Annales Alamannici, Annales Sangallenses maiores etc.), Mitteilungen zur Vaterländischen Geschichte, ed. Historischer Verein St. Gallen 19 (1884) 265-323.

Hoffmann, Hartmut, Grafschaften in Bischofshand, Deutsches Archiv für Erforschung des Mittelalters 46 (1990) 375-480.

Hoppenbrouwers, Peter, Leges nationum and ethnic personality of law in Charlemagne's Empire, in: Jeroen Duindam, Jill Harries, Caroline Humfress and Nimrod Hurvitz (eds.), Law and Empire. Ideas, Practices, Actors, Rulers and Elites (Oxford, 2013) 251-274.

Huschner, Wolfgang, Transalpine Kommunikation im Mittelalter. Diplomatische, kulturelle und politische Wechselwirkungen zwischen Italien und dem nordalpinen Reich (9.-11. Jahrhundert), (Hannover, 2003).

Innes, Matthew, Practices of property in the Carolingian Empire, in: Jennifer R. Davis and Michael McCormick (eds.), The Long Morning of Medieval Europe. New Directions in Early Medieval Studies (Aldershot, 2008) 247-266.

Jones, Arnold H. M., The Later Roman Empire 284-602. A Social, Economic and Administrative Survey, vol. 2 (Oxford, 1964).

Kaiser, Reinhold, Autonomie, Integration, bilateraler Vertrag - Rätien und das Frankenreich im frühen Mittelalter, Francia 29/1 (2002) 1-27. 
Kaiser, Reinhold, Bischofsherrschaft zwischen Königtum und Fürstenmacht. Studien zur bischöflichen Stadtherrschaft im westfränkischen-französischen Reich im frühen und hohen Mittelalter (Bonn, 1981).

Kaiser, Reinhold, Die Capitula Remedii: Veranlassung, Autorschaft und Geltungsgrund, Verbreitung und Wirkung, in: Reinhold Kaiser (ed.), Churrätien im frühen Mittelalter. Ende 5. bis Mitte 10. Jahrhundert (second edition), (Basel, 2008) 146-181.

Kaiser, Reinhold, Churrätien im frühen Mittelalter. Ende 5. bis Mitte 10. Jahrhundert (second edition), (Basel, 2008).

Kaiser, Reinhold, Steuer und Zoll in der Merowingerzeit, Francia 7 (1979) 1-17.

Kaiser, Wolfgang, Die Epitome Iuliani. Beiträge zum römischen Recht im frühen Mittelalter und zum byzantinischen Rechtsunterricht (Frankfurt am Main. 2004).

Kaiser, Wolfgang, Zur hundertjährigen Verjährung zugunsten der römischen Kirche, Zeitschrift der Savigny-Stiftung für Rechtsgeschichte, Kanonistische Abteilung 85 (1999) 60103.

Kasten, Brigitte, Der Kampf um die wirtschaftlichen Ressourcen zur Zeit König Konrads I., in: Hans-Werner Goetz (ed.), Konrad I. Auf dem Weg zum »Deutschen Reich«? (Bochum, 2006) 151-167.

Keller, Hagen, Die Ottonen (Munich, 2001).

Keller, Hagen, Zum Sturz Karls III. Über die Rolle Liutwards von Vercelli und Liutberts von Mainz, Arnulfs von Kärnten und der ostfränkischen Großen bei der Absetzung des Kaisers, Deutsches Archiv für Erforschung des Mittelalters 22 (1966) 333-384.

Kern, Fritz, Recht und Verfassung im Mittelalter, Historische Zeitschrift 120 (1919) 1-79.

Kerneis, Soazick, Une histoire juridique de l'Occident (IIIe-IXe siècle). Le droit et la coutume (Paris, 2018).

Kleindinst, Julia, Das churrätische Reichsguturbar - eine Quelle zur frühmittelalterlichen Geschichte Vorarlbergs, Montfort 47 (1995) 89-130.

Kleindinst, Julia, Das Folcwin Archiv, in: Karl Heinz Burmeister and Alois Niederstätter (eds.), Archiv und Geschichte. 100 Jahre Vorarlberger Landesarchiv (Konstanz, 1999) 99-120.

Kosto, Adam J., Making Agreements in Medieval Catalonia. Power, Order, and the Written Word, 1000-1200 (Cambridge, 2001).

Krug, Hansjörg, Untersuchungen zum Amt des centenaries - Schultheiß, Zeitschrift der Savigny-Stiftung für Rechtsgeschichte, Germanistische Abteilung 87 (1970) 1-31 and 88 (1971) 29-109.

Kuchenbuch, Ludolf, Abschied von der "Grundherrschaft" - Ein Prüfgang durch das ostfränkisch-deutsche Reich 950-1050, Zeitschrift der Savigny-Stiftung für Rechtsgeschichte, Germanistische Abteilung 121 (2004) 1-99.

Kuchenbuch, Ludolf, Ordnungsverhalten im grundherrlichen Schriftgut vom 9. bis zum 12. Jahrhundert, in: Johannes Fried (ed.), Dialektik und Rhetorik im früheren und hohen Mittelalter. Rezeption, Überlieferung und gesellschaftliche Wirkung antiker Gelehrsamkeit vornehmlich im 9. und 12. Jahrhundert (Munich, 1997) 175-268.

Kuchenbuch, Ludolf, Verrechtlichung von Erinnerung im Medium der Schrift (9. Jahrhundert), in: Aleida Assmann and Dietrich Harth (eds.), Mnemosyne. Formen und Funktionen der kulturellen Erinnerung (Frankfurt am Main, 1991) 36-47.

Lauranson-Rosaz, Christian, Des "mauvaises coutumes" aux »bonnes coutumes«. Essai de synthese pour le Midi (Ve-XIIe siècle), in: Mireille Mousnier and Jacques Poumarède (eds.), La coutume au village dans l'Europe médiévale et moderne (Toulouse, 2001) 19-51. 
Lauranson-Rosaz, Christian, Le mauvaises coutumes d'Auvergne (fin X-XI siècle), Annales du Midi 102 (1990) 557-586.

Lemarignier, Jean-François, La dislocation du pagus et le problème des consuetudines (Xe-XIe siècles), in: Mélanges d'histoire du moyen âge dédiés à la mémoire de Louis Halphen (Paris, 1951) 401-410.

Lendi, Walter, Untersuchungen zur frühalemannischen Annalistik. Die Murbacher Annalen (Freiburg, 1971).

Leopold Auer, Der Kriegsdienst des Klerus unter den sächsischen Kaisern, Mitteilungen des Instituts für Österrichische Geschichtsforschung 79 (1971) 317-407 and 80 (1972) 48-70.

Lex Romana Curiensis, ed. Elisabeth Meyer-Marthaler (second edition), (Aarau, 1966).

Liebrecht, Johannes, Fritz Kern und das "gute alte Recht». Geistesgeschichte als neuer Zugang für die Mediävistik (Frankfurt am Main, 2016).

Lübeck, Konrad, Vom Reichskriegsdienste des Klosters Fulda, Fuldaer Geschichtsblätter 28 (1936) 1-13 and 29 (1937) 55-64.

MacLean, Simon, Kingship and Politics in the Late Ninth Century. Charles the Fat and the End of the Carolingian Empire (Cambridge, 2003).

Magnou-Nortier, Elisabeth, Lex et consuetudo. Enquête dans les sources législatives carolingiennes, in: Coutumes et libertés. Actes des Journées internationales de Toulouse, 4-7 juin 1987 (Montpellier, 1988) 197-207.

Magnou-Nortier, Elisabeth, Les mauvaises coutumes en Auvergne, Bourgogne méridionale, Languedoc et Provence au XIe siècle: un moyen d'analyse sociale, in: Structures féodales et féodalisme dans l'Occident méditerranéen (Xe-XIIIe siècles). Bilan et perspectives de recherches (Rome, 1980) 135-172.

Maurer, Helmut, Der Herzog von Schwaben. Grundlagen, Wirkungen und Wesen seiner Herrschaft in ottonischer, salischer und staufischer Zeit (Sigmaringen, 1978).

Mazel, Florian, Féodalités (Historie de France, 2: 888-1180) (Paris, 2010).

Metz, Wolfgang, Das Kloster Weißenburg und der Vertrag von Verdun, in: Clemens Bauer, Laetitia Böhm and Max Müller (eds.), Speculum historiale. Geschichte im Spiegel von Geschichtsschreibung und Geschichtsdeutung. Johannes Spörl aus Anlass seines 60. Geburtstags dargebracht (Freiburg i. Br., 1965) 458-468.

Meyer-Marthaler, Elisabeth, Römisches Recht in Rätien im frühen und hohen Mittelalter (Zürich, 1968).

Mischke, Britta, Kapitularienrecht und Urkundenpraxis unter Kaiser Ludwig dem Frommen (814840). Unpublished $\mathrm{PhD}$ thesis (Bonn University, 2013).

Müller, Karl Otto, Eine neue Handschrift der Lex Romana Visigotorum (Breviarium Alaricianum) in churrätischer Schrift aus der Zeit um 800, Zeitschrift der Savigny-Stiftung für Rechtsgeschichte, Germanistische Abteilung 57 (1937) 429-442.

Murray, Alexander Callander, From Roman to Frankish Gaul. Centenarii and centenae in the administration of the Merovingian Kingdom, Traditio 44 (1988) 59-100.

Murray, Alexander C., Merovingian immunity revisited, History Compass 8 (2010) 913-928.

Niederstätter, Alois, Mancipia, servi et ancillae. Zur Frage der Unterschichten im frühmittelalterlichen Rätien, in: Wolfgang Hartung and Alois Niederstätter (eds.), Frühmittelalter zwischen Alpen und Bodensee. Untersuchungen zur Strukturgeschichte Vorarlbergs, vol. 1 (Dornbirn, 1990) 71-81.

Nobili, Mario, La malae consuetudines in Lungiana. Il documento del vescovo Eriberto gli homines di Trebbiano del 4 Novembre 1039, Memorie della Accademia Lungianese di Scienze, Lettere ed Arti Giovanni Capellini 75 (2005) 129-138. 
Noethlichs, Leo Karl, Materialien zum Bischofsbild aus den spätantiken Rechtsquellen, Jahrbuch für Antike und Christentum 16 (1973) 28-59.

Nörr, Dieter, Die Entstehung der longi temporis praescriptio. Studien zum Einfluss der Zeit im Recht und zur Rechtspolitik in der Kaiserzeit (Cologne, 1969).

Percival, John, The precursors of Domesday. Roman and Carolingian land registers, in: Peter H. Sawyer (ed.), Domesday book. A Reassessment (London, 1987) 5-27.

Piekenbrock, Andreas, Befristung, Verjährung, Verschweigung und Verwirkung. Eine rechtsvergleichende Grundlagenstudie zu Rechtsänderungen durch Zeitablauf (Tübingen, 2006).

Postel, Verena, Nobiscum partiri. Konrad I. und seine politischen Berater, in: Hans-Werner Goetz (ed.), Konrad I. Auf dem Weg zum »Deutschen Reich«? (Bochum, 2006) 129-149.

Prinz, Friedrich, Fortissimus abba. Karolingischer Klerus und Krieg, in: Joachim F. Angerer and Josef Lenzenweger (eds.), Consuetudines monasticae. Eine Festgabe für Kassius Hallinger aus Anlaß seines 70. Geburtstages (Rom, 1982) 61-95.

Prinz, Friedrich, Klerus und Krieg im frühen Mittelalter. Untersuchungen zur Rolle der Kirche beim Aufbau der Königsherrschaft (Stuttgart, 1971).

Das Prümer Urbar, ed. Ingo Schwab, Rheinische Urbare 5 (Düsseldorf, 1983).

Regino of Prüm, De synodalibus causis et disciplinis ecclesiasticis, ed. Friedrich Wilhelm Wasserschleben (Leipzig 1840).

Reuter, Timothy, The "Imperial Church System« of the Ottonian and Salian rulers. A reconsideration, Journal of Ecclastiastical History 33 (1982) 347-374.

Rio, Alice, Legal Practice and the Written Word in the Early Middle Ages. Frankish Formulae, $c$. 500-1000 (Cambridge, 2009).

Rio, Alice, Slavery after Rome 50o-110o (Oxford, 2017).

Schieffer, Rudolf, Der geschichtliche Ort der ottonisch-salischen Reichskirchenpolitik (Opladen, 1997).

Semmler, Josef, Traditio und Königsschutz. Studien zur Geschichte der königlichen monasteria, Zeitschrift der Savigny-Stiftung für Rechtsgeschichte, Kanonistische Abteilung 45 (1959) 1-33.

Siems, Harald, Recht in Rätien zur Zeit Karls des Großen - Ein Beitrag zu den Capitula Remedii, in: Hans Rudolf Sennhauser (ed.), Wandel und Konstanz zwischen Bodensee und Lombardie zur Zeit Karls des Großen (Zürich, 2013) 199-238.

Siems, Harald, Zur Lex Romana Curiensis, in: Heidi Eisenhut, Karin Fuchs, Martin Hannes Graf and Hannes Steiner (eds.), Schrift, Schriftgebrauch und Textsorten im frühmittelalterlichen Churrätien (Basel, 2008) 109-136.

Theodosiani libri XVI cum Constitutionibus Sirmondianis et Leges Novellae ad Theodosianum pertinentes, ed. Theodor Mommsen and Paul M. Meyer, 2 vols. (Berlin, 1905); English translation: Clyde Pharr, The Theodosian Code and Novels and the Sirmondian Constitutions. A Translation with Commentary, Glossary, and Bibliography (Princeton, 1952).

Die Urbare der Abtei Werden a. d. Ruhr, A: Die Urbare vom 9.-13. Jahrhundert, ed. Rudolf Kötzschke, Rheinische Urbare 2 (Bonn, 1906).

Vollrath, Hanna, Herrschaft und Genossenschaft im Kontext frühmittelalterlicher Rechtsbeziehungen, Historisches Jahrbuch 102 (1982) 33-71.

Vollrath, Hanna, Rechtstexte in der oralen Rechtskultur des früheren Mittelalters, in: Michael Borgolte (ed.), Mittelalterforschung nach der Wende 1989 (Munich, 1995) 319-348. 
Werner, Karl Ferdinand, Heeresorganisation und Kriegführung im deutschen Königreich des 10. und 11. Jahrhunderts, in: Ordinamenti militari in occidente nell'alto medioevo, vol. 2 (Spoleto, 1968) 791-843.

White, Stephen D., Bad customs (malae consuetudines) in eleventh-century France, in: Per Andersen and Mia Münster-Swendsen (eds.), Custom. The development and use of a legal concept in the Middle Ages (Copenhagen, 2009) 51-66.

Zeller, Bernhard, Über Romanen, Räter und Walchen im frühmittelalterlichen Churrätien, in: Walter Pohl, Ingrid Hartl and Wolfgang Haubrichs (eds.), Walchen, Romani und Latini. Variationen einer nachrömischen Gruppenbezeichnung zwischen Britannien und dem Balkan (Vienna, 2017) 153-162.

Zettler, Alfons, Geschichte des Herzogtums Schwaben (Stuttgart, 2003).

Zotz, Thomas, Erchanger, Lexikon des Mittelalters 3 (1986) col. 2123-2124. (FN 99)

Zotz, Thomas, König Konrad I. und die Genese des Herzogtums Schwaben, in: Hans-Werner Goetz (ed.), Konrad I. Auf dem Weg zum »Deutschen Reich«? (Bochum, 2006) 185-198.

Zuckerman, Constantin, Du village à l'Empire. Autour du Registre fiscal d'Aphroditô (525/526) (Paris, 2004). 